\title{
The Many Faces of Kefir Fermented Dairy Products: Quality Characteristics, Flavour Chemistry, Nutritional Value, Health Benefits, and Safety
}

\author{
Mohamed A. Farag ${ }^{1,2}, *$, Suzan A. Jomaa ${ }^{2}$, Aida Abd El-Wahed ${ }^{3,4}$ and \\ Hesham R. El-Seedi $4,5,6,7, *$ (D) \\ 1 Pharmacognosy Department, College of Pharmacy, Cairo University, Kasr El Aini St., P.B., Cairo 11562, Egypt \\ 2 Chemistry Department, School of Sciences \& Engineering, The American University in Cairo, \\ New Cairo 11835, Egypt; suzyaj@aucegypt.edu \\ 3 Department of Bee Research, Plant Protection Research Institute, Agricultural Research Centre, Giza 12627, \\ Egypt; aidaabd.elwahed@arc.sci.eg \\ 4 Pharmacognosy Group, Department of Medicinal Chemistry, Uppsala University, Biomedical Centre, \\ Box 574, SE-751 23 Uppsala, Sweden \\ 5 Al-Rayan Research and Innovation Center, Al-Rayan Colleges, Medina 42541, Saudi Arabia \\ 6 International Research Center for Food Nutrition and Safety, Jiangsu University, Zhenjiang 212013, China \\ 7 Department of Molecular Biosciences, The Wenner-Gren Institute, Stockholm University, \\ SE 10691 Stockholm, Sweden \\ * Correspondence: Mohamed.farag@pharma.cu.edu.eg or mfarag73@yahoo.com (M.A.F.); \\ hesham.el-seedi@ilk.uu.se (H.R.E.-S.); Tel.: +20-011-202-2362245 (M.A.F.); +46-18-4714496 (H.R.E.-S.)
}

Received: 22 November 2019; Accepted: 18 January 2020; Published: 28 January 2020

\begin{abstract}
Kefir is a dairy product that can be prepared from different milk types, such as goat, buffalo, sheep, camel, or cow via microbial fermentation (inoculating milk with kefir grains). As such, kefir contains various bacteria and yeasts which influence its chemical and sensory characteristics. A mixture of two kinds of milk promotes kefir sensory and rheological properties aside from improving its nutritional value. Additives such as inulin can also enrich kefir's health qualities and organoleptic characters. Several metabolic products are generated during kefir production and account for its distinct flavour and aroma: Lactic acid, ethanol, carbon dioxide, and aroma compounds such as acetoin and acetaldehyde. During the storage process, microbiological, physicochemical, and sensory characteristics of kefir can further undergo changes, some of which improve its shelf life. Kefir exhibits many health benefits owing to its antimicrobial, anticancer, gastrointestinal tract effects, gut microbiota modulation and anti-diabetic effects. The current review presents the state of the art relating to the role of probiotics, prebiotics, additives, and different manufacturing practices in the context of kefir's physicochemical, sensory, and chemical properties. A review of kefir's many nutritional and health benefits, underlying chemistry and limitations for usage is presented.
\end{abstract}

Keywords: kefir; composition; physicochemical properties; sensory characters; nutritional value; biological effects

\section{Introduction}

Kefir is a fermented milk drink with an acidic taste and creamy consistency produced by bacterial fermentation of kefir grains. The term kefir is derived from the word kef, which means 'pleasant taste' in Turkish. Kefir grains are the natural starter for kefir and are recovered after the fermentation process. The grains contain a mixture of microorganisms (bacteria and yeast), which coexist and interact to produce a unique fermented dairy product [1]. Kefir is prepared from raw cow, camel, goat, sheep, 
or buffalo milk mixed with kefir grains [2,3]. Kefir's chemical composition depends not only on the starter-kefir grains but also on its geographical origin, the temperature, and time-related conditions of fermentation, and especially on the type and volume of the milk used [1,4]. The characteristic smell and flavour of kefir are due to the volatile and non-volatile compounds generated upon fermentation via lipolysis, glycolysis, and proteolysis. The physicochemical properties of kefir include an acidic $\mathrm{pH}$ of 4.6 , alcohol of $0.5 \%-2 \%$, acidic taste, and yeasty flavour. Additionally, carbon dioxide produced by the yeast flora contributes to its sharp acid and yeasty flavour [5].

Kefir is proposed as one of the factors associated with the long life expectancy of the people of Caucasus, owing to its many health benefits such as anti-stress properties, immune-modulation [6], cholesterol-lowering [7], anti-allergenic [8], anti-asthmatic, anti-microbial [9], anticancer properties [10] and chemoprevention against colon cancer [11], aside from its gastrointestinal beneficial effects [12].

Such health benefits are attributed to kefir's protein, vitamin, lipid, mineral, amino acid, and microelement composition. Moreover, the fermentation process enriches the content of vitamins B1, B12, K, folic acid, calcium and amino acids [13], adding to kefir's health benefits.

This review focuses on kefir's physiochemical, sensory analysis and flavour composition in terms of how different production methods and ingredients affect the composition of kefir and ultimately affect its biological and nutritive values.

\section{Prebiotic, Additives, and Production Methods Employed in Kefir Production}

Several schemes can be employed for kefir production, all sharing the same underlying principle. Kefir is first prepared by mixing two types of milk, such as mare, goat or sheep milk [14], or by adding additives such as native inulin, to improve its beneficial effect and final texture [15]. An alternative way of producing kefir is to utilize non-dairy substrates such as fruits and molasses to produce sugary kefir, which has unique sensory properties, such as a refreshing flavour due to the presence of ethanol, a fruity aroma due to the presence of esters and a body and texture attributed to its glycerol content [16].

The traditional method of preparing dairy-based kefir used in private households is to incubate milk with kefir grains. The kefir grains are inoculated into sterilized milk and fermented at $25{ }^{\circ} \mathrm{C}$ until a pH of 4.4 is reached. The grain and milk are then separated using a sterilized plastic filter at the end of the fermentation process [17]. In contrast, water kefir is a homemade fermented beverage based on a sucrose solution with different dried and fresh fruits. In the traditional process of sugary kefir preparation, kefir grains are placed into a solution containing $8 \%$ sucrose, dried fruits (typically figs) and some slices of lemon. Fermentation for one or two days at room temperature results in a cloudy, carbonated and straw-coloured drink, poor in sugar, slightly alcoholic, and acidic [18].

Backslopping is a technique used in the production of fermented food such as sourdough, idli, sauerkraut, dry sausage, beer, cheese and kefir [19]. The milk is first pasteurized at $90{ }^{\circ} \mathrm{C}$ for $15 \mathrm{~min}$ and is then cooled to $25^{\circ} \mathrm{C}$ to improve its microbiological quality. The cooled milk is mixed with $5 \%$ kefir grains and incubated at $18-24{ }^{\circ} \mathrm{C}$ for $18 \mathrm{~h}$, and the kefir grains are later separated via a sieve under aseptic conditions. The kefir is then stored at $4{ }^{\circ} \mathrm{C}$ (Figure 1 ). The fermentation step is used to speed up the microorganisms' action and the metabolic changes occurring in milk composition [20]. A backslopping strategy is employed to increase kefir beverage generation, with a 50-fold production yield increase while maintaining the same kefir characteristics (physicochemical, microbiological and nutritional value) as traditional kefir except for the differences in the lactobacillus kefir population (7.94 vs. $8.89 \log$ CFU/mL) and decreased yeast count (7.1 vs. $5.22 \log$ CFU/mL) [17]. This method is considered cheap and reliable, especially in less developed countries, with only a few shortcomings observed in product consistency and microbiological diversity.

Kefir production faces more than one challenge, owing to the unique and diverse microflora of kefir grain, milk type, incubation time and storage conditions. The sensory, physicochemical properties and the quality of kefir products hindered the mass production of kefir on an industrial scale [21]. Such limitations may be due to the microbial diversity and interaction that influence the final product quality. Additional study is warranted to improve and standardise production at an industrial level [22]. 


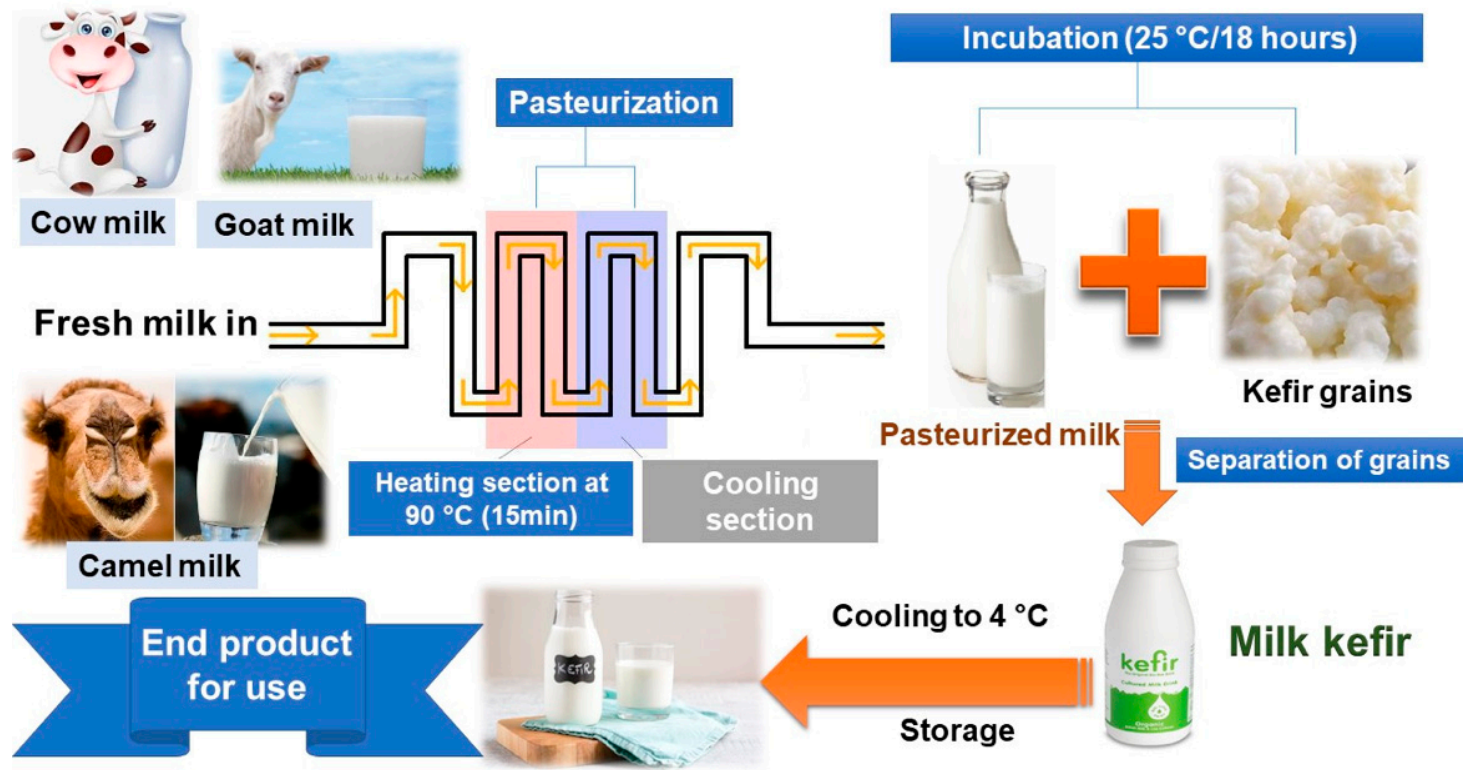

Figure 1. Outline diagram representing the backslopping method used for kefir production.

Due to kefir's short shelf life and high storage and packaging costs, the trend towards having dry kefir in powder form appears warranted. Both spray drying and freeze drying are used to produce powdered kefir [23]. Spray drying is the most common technique employed in the dairy powder industry due to its reduced cost, quick drying time, efficient drying and efficient moisture removal levels. However, in spray drying, some decrease in microorganism viability occurs concurrently with a loss of aroma and flavour. Factors that affect the survival of kefir bacteria after drying include spray drying inlet and outlet temperatures, atomization type, direction of airflow and initial microorganism counts [24]. Freeze drying is known as the best drying process and can maintain sensory properties and the viability of the bacteria. However, freeze drying has a high cost and longer processing time that constrict its use in the food industry [25,26]. For mass production, spray drying is accepted for its product stability; however, the main limitation is the loss of microorganism viability during the drying process [23].

Altogether, these results show that kefir production is influenced by several factors including raw materials, production technology, and storage conditions that all need to be optimized in parallel to achieve the best product quality.

\section{Physicochemical Parameters of Kefir in the Context of Its Different Production Methods}

Typical kefir consists of $90 \%$ moisture, $3.0 \%$ protein, $0.2 \%$ lipid, $6.0 \%$ sugar, $0.7 \%$ ash, $1.0 \%$ lactic acid, $0.48 \%$ alcohol and $201.7-277.0 \mathrm{~mL} / \mathrm{L} \mathrm{CO}_{2}$, all of which are dependent on the amount of kefir grain [1]. The chemical composition of kefir depends mostly on the type of milk used, the grains, or mixture of cultures, additives and the technology employed in its production. Figure 2 shows an outline of these variables [27]. The composition of dry matter, fat, protein, total carbohydrates, and ash content depends on the milk type. Cow milk kefir was found to be enriched in protein, fat, and lactose compared to that prepared using camel milk, concurrent with low dry matter and ash content [3]. The alcohol, protein, fat and ash levels were found to be influenced by kefir grain levels and $\mathrm{pH}$ fermentation. For example, using $1 \%$ kefir grain at a $\mathrm{pH}$ of 4.5 led to a decrease in alcohol level to $0.3 \%$ in goat milk kefir, compared to $1 \%$ alcohol when using $5 \%$ kefir grain at the same $\mathrm{pH}$ value [28]. Such a decrease in alcohol level in kefir can be favoured in certain parts of the world, e.g., Islamic countries in which alcoholic beverages are not allowed. 


\begin{tabular}{|c|c|}
\hline Buffalo & Goat \\
\hline Cow & Mare \\
\hline Sheep & Camel \\
\hline \multicolumn{2}{|c|}{ Lactobacillus spp. } \\
\hline L. kefiranofaciens & L. brevis \\
\hline L. Casei & L. kefiri \\
\hline L. paracasei & L. nageliii \\
\hline L. hilgardii & L. hordei \\
\hline \multicolumn{2}{|c|}{ Lactococcus spp. } \\
\hline L. lactis & L. cremoris \\
\hline \multicolumn{2}{|c|}{ Streptococcusspp. } \\
\hline S. thermophilus & S. durans \\
\hline \multicolumn{2}{|c|}{ Pediococcus spp. } \\
\hline P. dextrinicus & P. acidilactici \\
\hline Inulin & Fruits \\
\hline Vitamin D,E,C & $\mathrm{Ca}, \mathrm{Mg}$ \\
\hline
\end{tabular}

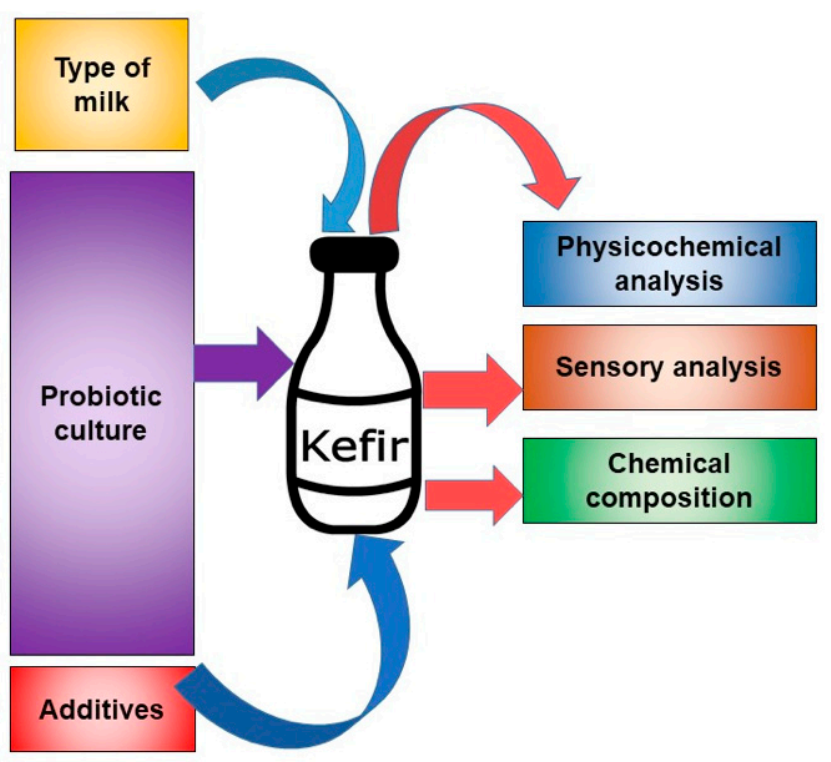

Figure 2. Major variables including milk, culture and additives employed in kefir production that affect quality and chemical composition.

The starter culture employed in kefir production exhibits a significant effect on its viscosity and on chemical composition [22]. The kefir microbial community encompasses a complex mixture of lactic acid bacteria (LAB) (Leuconostocs, Lactobacilli, Streptococci, lactococci, Enterobacter, Acinetobacter, Enterococcus, and Pseudomonas spp.), acetic acid bacteria and yeasts (Kluyveromyces, Candida, Torulopsis, Saccharomyces, Rhodotorula and Zygosaccharomyces) (Table 1) [14,29]. Yeast plays a vital role in establishing an environment that allows for the growth of kefir bacteria, aside from the production of several key metabolites such as peptides, amino acids, vitamins, ethanol and $\mathrm{CO}_{2}$ that contribute ultimately to kefir's flavour and aroma $[30,31]$ and its several health benefits. In Brazil, kefir grains are used to ferment milk in private households. Brazilian kefir is characterized by the presence of three microbial populations: yeast (Saccharomyces cerevisiae), lactic acid bacteria and gram-negative bacteria (Lactobacillus paracasei) to yield kefir with lactic acid, alcohol and acetic acid. Chemical analysis revealed that the highest concentration of lactic acid $(7.30 \mathrm{mg} / \mathrm{mL})$, followed by acetic acid $(6.50 \mathrm{mg} / \mathrm{mL})$ and malic acid $(4.00 \mathrm{mg} / \mathrm{mL})$ is observed in cow milk kefir fermentation [32]. The increase in lactic acid bacterial population was found to be correlated with an increase in lactic acid levels [33], and aside from imparting the unique taste in kefir, lactic acid inhibits microorganism growth owing to decrease in $\mathrm{pH}$ acting as an acidulant preservative. In contrast, yeast (S. cerevisiae) mediates for aroma production in kefir alongside other volatile esters such as isopentyl acetate, ethyl hexanoate, ethyl octanoate, phenethyl acetate, and ethyl decanoate [34,35]. Esters are recognized for their distinctive aroma in many herbs and appear to be responsible for the predominant aromas in kefir. Tibetan kefir is characterized by Lactobacillaceae, Streptococcaceae and Leuconostocaceae families [36]. In the manufacture of Tibetan kefir, a combination of different microorganism species from Lactococcus lactis, Leuconosroc mesenteroides, Lactobacillus kefir, Lactobacillus casei, and Kluyveromyces marxianus are employed and produce diacetyl, ethanol, and $\mathrm{CO}_{2}$ at $77.23 \mathrm{mg} / \mathrm{L}, 4259 \mathrm{mg} / \mathrm{L}$, and $2.12 \mathrm{~g} / \mathrm{L}$, respectively (Table 1) [37].

During the fermentation of skim milk powder with kefir starter culture, volatile kefir flavour compounds were monitored using the headspace solid-phase micro-extraction (HS-SPME) method. Eight volatile flavour compounds were detected, including ethanol (39.3\%), 2-butanone $(31.6 \%)$, ethyl acetate $(8.9 \%)$, ethyl butyrate (5.5\%), acetone (3.6\%), 3-hydroxy-2-butanone (acetoin, 3.3\%), 2,3-butanedione (diacetyl, 2.9\%) and acetaldehyde (1.7\%), representative of the alcohol, ketone, ester and aldehyde classes, respectively (Figure 3). Additionally, acetone, diacetyl, ethanol, acetaldehyde and ethyl acetate increased during fermentation [38]. 


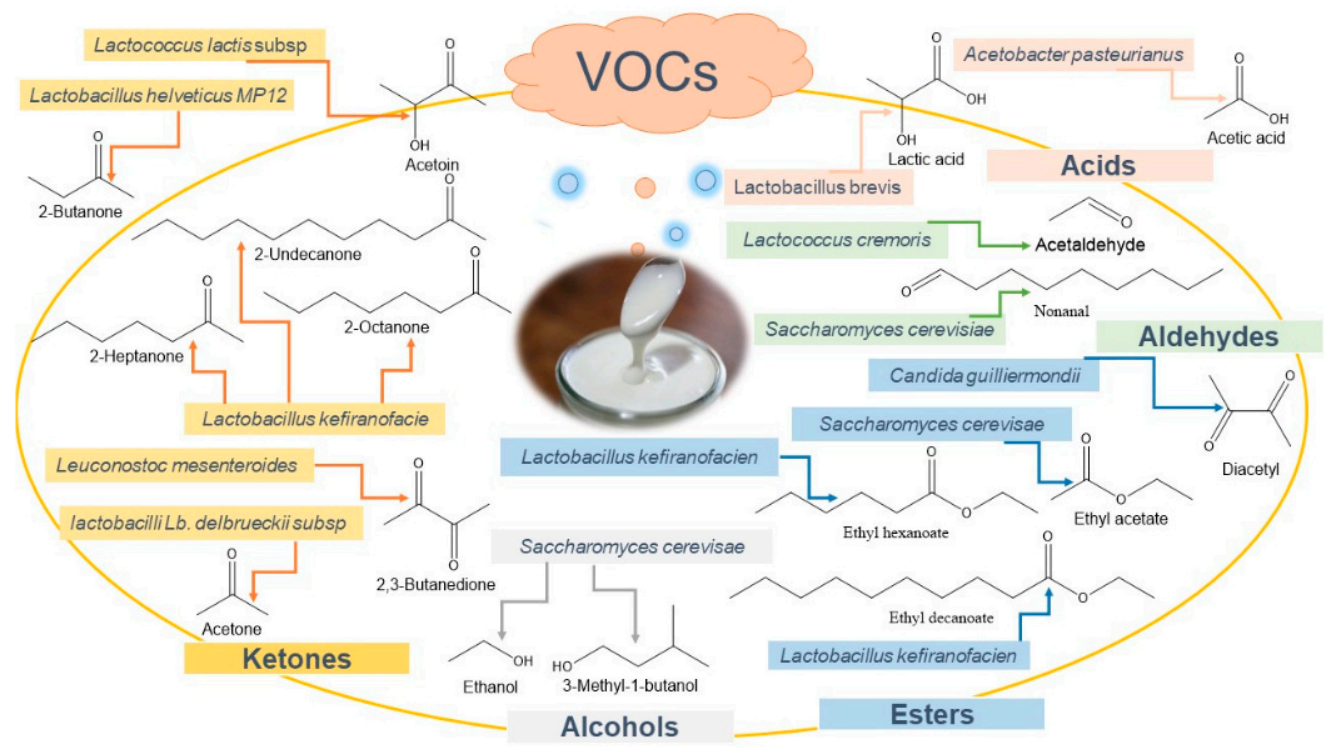

Figure 3. Major volatile aroma compound classes produced in kefir during fermentation.

Free fatty acids (FFAs) produced via lipolysis in milk are responsible for the taste and aroma of several fermented milk products, including kefir (Figure 4). Indeed, fermented milk was found to contain from 5 to 10 times more FFAs than milk. For example, incubation of sheep milk inoculated with a kefir culture led to a 4.3 fold increase of its FFAs [39]. FFAs in kefir prepared using sheep milk incubated at two temperatures $\left(23^{\circ} \mathrm{C}\right.$ and $26^{\circ} \mathrm{C}$, each for $16-18 \mathrm{~h}$ ) showed a higher amount of FFAs at the lower temperature, concurrent with lower acetaldehyde and diacetyl levels [40]. From a sensory point of view, kefir produced at the higher temperature $\left(26^{\circ} \mathrm{C}\right)$ was more desirable than that produced at $23^{\circ} \mathrm{C}$. The polyunsaturated fatty acid ratio in the camel milk kefir was found to be lower than that of cow milk kefir, concurrent with a higher Lactobacillus ssp. count in cow milk kefir [3]. The low abundance of microbes in camel milk is attributed to the bacteriocin peptide which exhibits an antimicrobial effect that has yet to be determined.

\section{Kefir Flavour Chemistry Production}

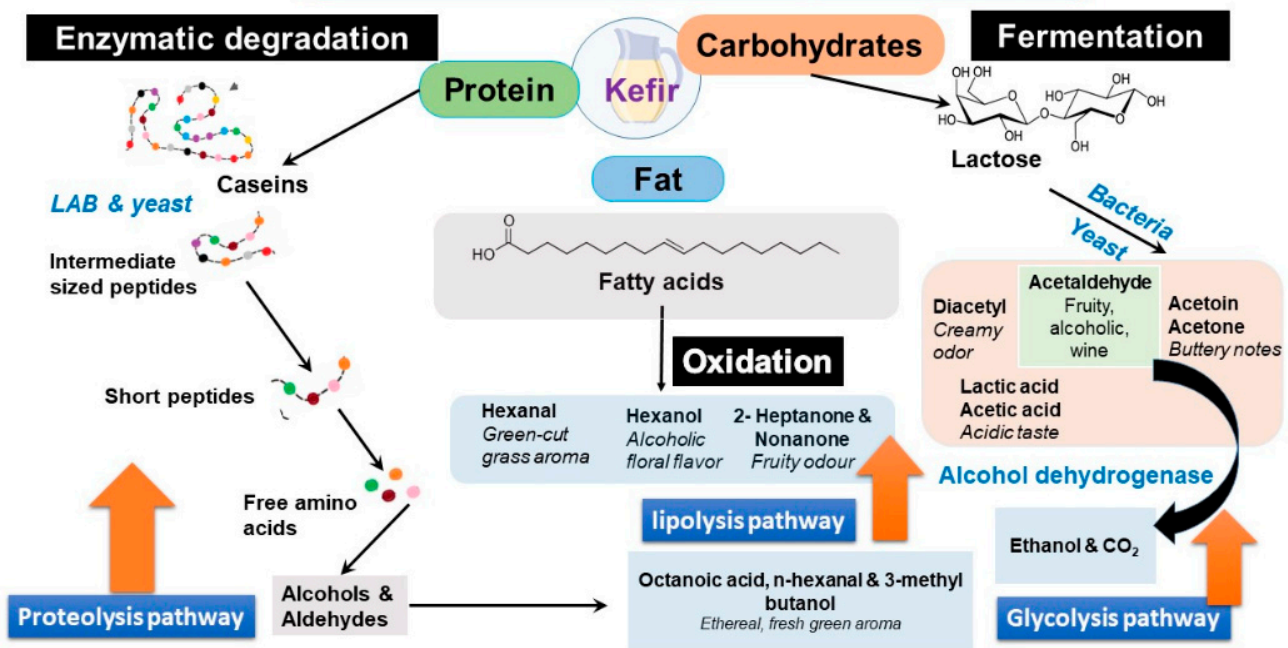

Figure 4. Kefir flavour chemistry production via proteolysis, lipolysis and glycolysis of milk macronutrients by the action of different microbes within kefir grains. 
Table 1. List of microorganisms isolated from kefir grains, their chemical end products, and odour descriptors as typical in fermented dairy products.

\begin{tabular}{|c|c|c|c|}
\hline Microorganisms (Kefir Type) & Produced Metabolites & Odor and FlavorDescription & Reference \\
\hline $\begin{array}{c}\text { Lactobacillus kefiranofaciens (Tibetan kefir) } \\
\text { Lactobacillus acidophilus Z1L (Turkish homemade } \\
\text { Lactobacillus brevis } \\
\text { Lactobacillus helveticus Z5L } \\
\text { Lactobacillus casei Z7L1 (Turkish homemade ke } \\
\text { Lactobacillus harbinensis (Water kefir) } \\
\text { Leuconostoc mesenteroides } \\
\text { Lactococcus cremoris } \\
\text { Lactococcus lactis } \\
\text { Streptococcus durans } \\
\text { Pediococcus dextrinicus ZN1P } \\
\text { Pediococcus acidilactici ZN10P } \\
\text { Pediococcus pentosaceus ZN13P (Candida kefi } \\
\text { Candida guilliermondii } \\
\text { Saccharomyces Jorentinus (Sugar kefir) }\end{array}$ & Lactic acid & Sour flavor & [41-48] \\
\hline $\begin{array}{c}\text { Lactobacillus harbinensis (Water kefir) } \\
\text { Leuconostoc mesenteroides } \\
\text { Acetobacter pasteurianus } \\
\text { Lactococcus cremoris }\end{array}$ & Acetic acid & Vinegar, green, fruity, sour & [43] \\
\hline $\begin{array}{c}\text { Lactobacillus kefiri } \\
\text { Lactobacillus harbinensis } \\
\text { Lactobacillus hilgardii (Water kefir) } \\
\text { Leuconostoc mesenteroides (Candida kefir) } \\
\text { Saccharomyces turicensis } \\
\text { Saccharomyces florentinus } \\
\text { Kluyveromyces marxianus }\end{array}$ & Ethanol & Alcoholic flavor & {$[35,43-45,48-52]$} \\
\hline $\begin{array}{c}\text { Lactobacillus Brevis } \\
\text { Lactobacillus kefiri } \\
\text { Leuconostoc mesenteroides (Candida kefir) } \\
\text { Saccharomyces turicensis } \\
\text { Saccharomyces cerevisae } \\
\text { Pichia Kurdriavzevii }\end{array}$ & $\mathrm{CO}_{2}$ & Sharp odor and a sour taste & {$[45,51-53]$} \\
\hline Lactobacillus kefiranofaciens & Octanoic acid & Cheesy, rancid, pungent, sweet, soapy, goaty & [54] \\
\hline $\begin{array}{l}\text { Lactobacillus kefiranofaciens (Tibetan kefir) } \\
\text { Lactobacillus kefiri (Brazilian kefir) }\end{array}$ & Kefiran & - & [41] \\
\hline
\end{tabular}


Table 1. Cont.

\begin{tabular}{|c|c|c|c|}
\hline Microorganisms (Kefir Type) & Produced Metabolites & Odor and FlavorDescription & Reference \\
\hline Lactobacillus kefiranofaciens & n-Decanoic acid & Soapy, waxy, stale, buttery, fruity, grassy, cheesy, milky & [54] \\
\hline Lactobacillus kefiranofaciens & Ethyl decanoate & Fruity, grape, cognac & [54] \\
\hline Lactobacillus kefiranofaciens & Ethyl hexanoate & Animal, cardboard & [54] \\
\hline $\begin{array}{r}\text { Lactobacillus nagelii, Lactobacillus hilgardii } \\
\text { Lactobacillus hordei (Water kefir) } \\
\text { Lactobacillus plantarum YW11 (Tibet Kefir } \\
\text { Lactobacillus acidophilus Z1L (Turkish homemad } \\
\text { Lactobacillus helveticus Z5L } \\
\text { Lactobacillus casei Z7Ll } \\
\text { Lactococcus cremoris Z11S \& } \\
\text { Lactococcus lactis Z3S (Turkish homemade ke } \\
\text { Pediococcus dextrinicus ZN1P } \\
\text { Pediococcus acidilactici ZN10P } \\
\text { Pediococcus pentosaceus ZN13P } \\
\text { Kazachstania unispora }\end{array}$ & Exopolysaccharides (EPS) & & {$[18,42,55,56]$} \\
\hline Lactobacillus kefiranofaciens DN1 & New exopolysaccharide (EPS), EPS_DN1 & - & [57] \\
\hline $\begin{array}{c}\text { Lactobacillus acidophilus Z1L \& } \\
\text { Lactococcus cremoris Z11S (Turkish homemade } \\
\text { Pediococcus dextrinicus ZN1P } \\
\text { Pediococcus acidilactici ZN10P } \\
\text { Pediococcus pentosaceus ZN13P } \\
\text { Candida guilliermondii } \\
\text { Streptococcus thermophiles }\end{array}$ & $\mathrm{H}_{2} \mathrm{O}_{2}$ & - & {$[42,46,47]$} \\
\hline $\begin{array}{c}\text { Lactobacillus hilgardii } \\
\text { Saccharomyces florentinus (Sugar kefir) }\end{array}$ & Pyruvate & - & {$[48,50]$} \\
\hline $\begin{array}{c}\text { Lactobacillus hilgardii } \\
\text { Saccharomyces florentinus (Sugar kefir) }\end{array}$ & Propionate & - & {$[48,50]$} \\
\hline $\begin{array}{c}\text { Lactobacillus hilgardii } \\
\text { Saccharomyces florentinus (Sugar kefir) }\end{array}$ & Acetate & - & {$[48,50]$} \\
\hline $\begin{array}{c}\text { Lactobacillus hilgardii } \\
\text { Saccharomyces florentinus (Sugar kefir) }\end{array}$ & Succinate & - & {$[48,50]$} \\
\hline $\begin{array}{c}\text { Lactobacillus hilgardii } \\
\text { Saccharomyces florentinus (Sugar kefir) }\end{array}$ & Fumarate & - & {$[48,50]$} \\
\hline
\end{tabular}


Table 1. Cont.

\begin{tabular}{|c|c|c|c|}
\hline Microorganisms (Kefir Type) & Produced Metabolites & Odor and FlavorDescription & Reference \\
\hline Lactobacillus hilgardii (Sugar kefir) & Mannitol & - & {$[48,50]$} \\
\hline Leuconostoc mesenteroides & 2,3-Butanedione & Buttery flavors & {$[43,46,47]$} \\
\hline $\begin{array}{l}\text { Lactococcus cremoris } \\
\text { Streptococcus thermophilus } \\
\text { Streptococcus durans } \\
\text { Candida guilliermondii }\end{array}$ & Acetaldehyde & Fruity, alcoholic, wine & [47] \\
\hline Candida guilliermondii & Diacetyl & Creamy odor & {$[18,35,41,50]$} \\
\hline $\begin{array}{c}\text { Saccharomyces cerevisae } \\
\text { (Brazilian kefir, water kefir, and Tibetan kefir grains) }\end{array}$ & Glycerol & - & {$[18,35,41,50]$} \\
\hline Saccharomyces cerevisae & Nonanal & Green, citrus, fatty, floral & [54] \\
\hline Saccharomyces cerevisae & Phenylethyl alcohol & Unclean, rose, violet-like, honey, floral, spicy & [54] \\
\hline Saccharomyces cerevisae & Octanal & Green, fatty, soapy, fruity, orange peel & [54] \\
\hline Saccharomyces cerevisae & Ethyl acetate & Solvent, pineapple, fruity, apples & [54] \\
\hline Saccharomyces cerevisae & 3-Methyl-butanol & Penetrating, alcohol, wine-like, plastic & [54] \\
\hline
\end{tabular}

(-) Represents unreported. 
With regard to major volatile classes contributing to kefir's aroma, alcohol (e.g., ethanol), ketone (e.g., 3-hydroxy-2-butanone (acetoin and 2-butanone), ester (e.g., ethyl acetate) and aldehyde (e.g., acetaldehyde) were detected (Figures 3 and 4). Among volatiles generated during kefir production, the content of 2-butanone was found to be stable during fermentation in contrast to ethanol. Acetoin levels depended on $\mathrm{pH}$ and were found to significantly decrease at $\mathrm{pH}$ values from 4.6 till 5 [33,38]. These findings suggest that acetoin and alcohol could provide a better readout of kefir manufacturing conditions than monitoring only 2-butanone.

Metabolomic profiling is an analytical tool that has the potential to further the identification of the components of kefir and to monitor biochemical changes due to bacterial activity and or moreover upon storage.

\section{Sensory Analysis of the Different Kefir Types}

Kefir should exhibit acceptable aroma, flavour, and good mouthfeel properties to meet consumers' requests, all of which relate to its rheological properties. These characteristics are influenced first by the milk type used and its effect on kefir properties (textural, rheological and organoleptic properties). Kefirs produced from camel, cow, goat or ewe milk were found to have similar microbiological properties [58]. The addition of polysaccharide $(0.2 \%$ xanthan) or pomegranate extract led to an increase in kefir's stability with the best rheological and sensory properties [59,60]. The use of buffalo or cow milk with kefir grains and starter cultures was examined, with buffalo kefir found to exhibit higher viscosity and consistency with fewer modulus values compared to that made from cow milk [61]. Buffalo kefir exhibits higher yeast content resulting in a significant increase in ethanol level. The occurrence of ethanol gives the exotic, refreshing aroma of buffalo kefir [61]. Panelists judged the buffalo kefir as having improved sensory and colour properties compared to the cow kefir, suggesting that a combination of buffalo and cow milk could help improve kefir's overall quality [61]. The addition of 2\% kefir grain in goat milk improved the sensory quality; a white colour, typical kefir scent, and a non-acid taste were observed [62].

When flavour attributes in kefir, such as sour, sweet, salty, bitter, creamy, cheesy, sharp, gas, alcohol and metallic flavour tastes were compared, camel and cow milk kefirs scored differently. Camel milk kefir sample was found to be more sour, cheesy and have a sharper aroma than kefir prepared from cow milk, though its consistency and appearance had a lower score than that of cow milk kefir. Camel milk kefir received an overall better preference score from the panelists, mostly on account of its higher sourness [3].

Kefir prepared using non-animal milk, i.e., soymilk and $2 \%$ sucrose, exhibited acceptable flavour and aroma compounds. After two weeks of the cold storage, decreased levels of ethanol, acetaldehyde, diacetyl, and acetoin were noted [63]. There was no significant difference between the use of cow-soy milk mixture and cow milk in relation to $\mathrm{pH}$ and the acidity values or the stability of acidity during the storage period [5], while the addition of pomegranate juice and honey influenced its physicochemical, rheological and sensory properties. The addition of less than $5 \%$ pomegranate juice reduced $\mathrm{pH}$ value concurrent with an increase in viscosity, while the addition of more than $5 \%$ pomegranate juice substantially reduced protein and kefran concentration. Sensory analysis revealed that the addition of honey at $2.5 \%$ reduced acidity with an increase in viscosity and sweetness [64], aside from the myriad of health benefits of honey itself.

The formation of polyunsaturated fatty acids (PUFAs) in kefir made from goat and sheep milk was reported. PUFAs were found to affect the kefir aroma profile significantly. Increasing PUFA content led to the loss of the typical whey aroma (aromatics associated with whey powder) in goat kefir whereas the creamy aroma (aromatics associated with milk fat) became more prevalent in the case of sheep kefir [2].

The addition of thickening-agent additives, such as inulin, during kefir production did not significantly affect its chemical, microbial composition, odour or flavour, though it exhibited a higher viscosity value $[15,61]$. Thickening agents are likely to improve kefir's overall stability and/or shelf life 
as in case of acidophilus milk. The addition of $1 \%(\mathrm{w} / \mathrm{v})$ glucose and $10 \%$ grain for camel milk led to a reduction in its protein, fat, lactose content, viscosity, ash, dry matter, and titratable acidity compared to camel milk. Nevertheless, the higher cholesterol level $(18.24 \mathrm{vs.} 7.97 \mathrm{mg} / 100 \mathrm{~g})$ in camel-based kefir might present a disadvantage compared to cow-based kefir if hyperlipidemia is a limiting factor for consumers [3]. Mare's milk and a mixture of mare, goat and sheep milk were fermented using mesophilic LAB and produced kefir found to be firmer, and of higher consistency and viscosity, than mare's milk alone [14]. The functional properties of goat kefir would present an added advantage to the human daily diet in the form of high protein, fat, total solids, vitamins and minerals [65], affirming why the inclusion of more than one type of milk is favoured for kefir production.

In summary, aroma, flavour and good mouthfeel properties appear to be influenced by additives such as kefir grain, inulin, and sucrose, whereas milk type influenced kefir's textural and rheological properties.

\section{Kefir's Nutritional Value \& Health Benefits}

The number of fermented dietary supplements in the market has recently increased, owing to increased health awareness and lifestyle changes supporting (supposedly) healthy foods worldwide [33]. The nutritional values of kefir are due to its rich chemical composition, including minerals, sugars, carbohydrates, proteins, peptides, vitamins and fats (Figure 5). Aside from such chemical makeup, it is the fermentation process that further enhances kefir's nutritional value owing to secondary bioactive ingredients such as catechin, vanillin, ferulic acid, and salicylic acid. The latter has been identified in kefir produced from peanut milk [66]. Kefir is enriched in vitamins B1, B2, B5 and C, minerals and essential amino acids that are of value for improving fitness, the healing process and homeostasis. The vitamin composition in kefir is affected by the type of milk and microbiological flora used in its production. Propionibacterium peterssoni and Propionibacterium pituitosum produced vitamin B12, whereas Freudenreichii subsp. Propionibacterium Shermanii supported more vitamin B6 production [67]. Kefir is rich in the amino acids serine, threonine, alanine, lysine, valine, isoleucine, methionine, phenylalanine and tryptophan, which play a major role in the central nervous system. Kefir also contains partially digested proteins (e.g., caseins) that aid in its digestion and absorption by the body [68]. The essential amino acids found in abundance in kefir also regulate protein, glucose and lipid metabolism and exhibit a positive effect on the regulation of body weight, maintenance of immune response and energy balance. Amino acids prevent disability and prolong the healthy life expectancy of elderly subjects [69,70], and the branched-chain amino acids that are also found in kefir improve the cognitive recovery of patients with severe traumatic brain injury [70].

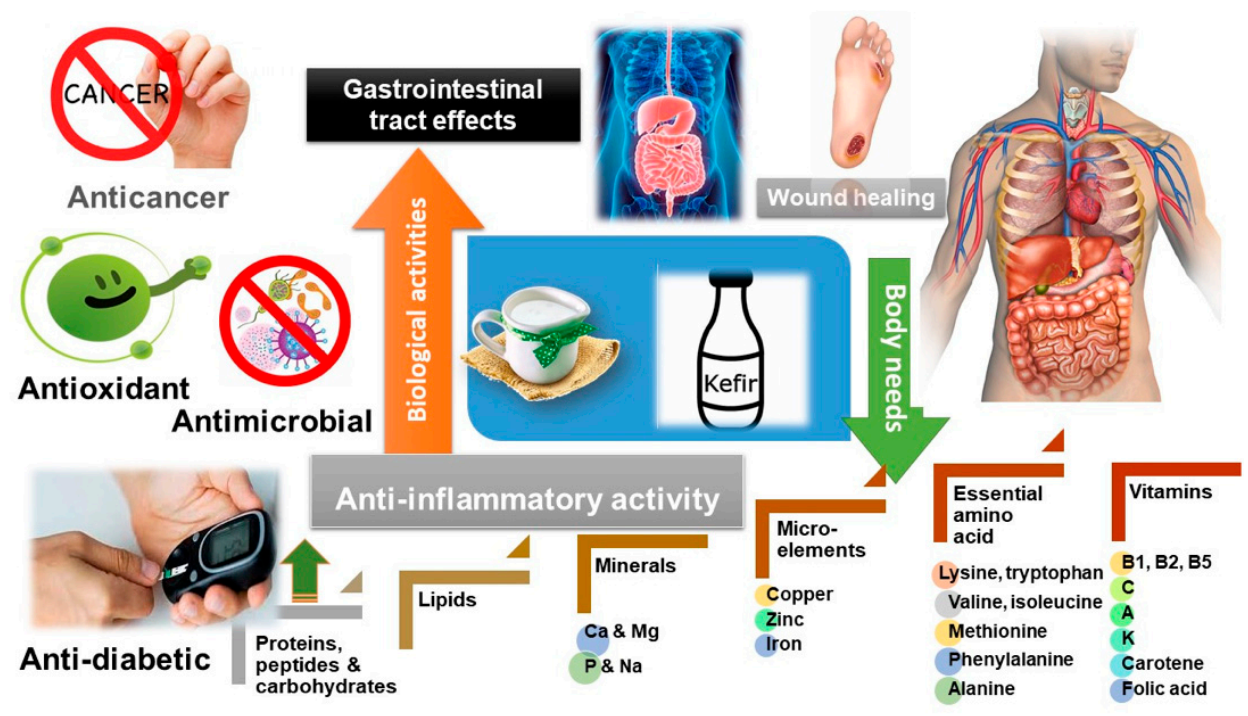

Figure 5. Biological properties, nutritional value, and macro- and micronutrient composition of kefir. 
Macro-elements enriched in kefir include calcium, magnesium, potassium, and sodium that aid in the utilization of carbohydrates, fats and proteins for cell growth, maintenance, and energy. Kefir also contains micro-elements, including iron, zinc, and copper, which are of special value in cellular metabolism and blood production [71].

Peptides are regarded as a unique and important class of compounds generated during milk fermentation and account for much of fermented milk products' health benefits. In Brazil, fermented sheep's milk provides a good source of bioactive peptides that exhibit antioxidant and antimicrobial activities [72]. The peptide F3 was purified from Tibetan kefir and exhibited antibacterial properties against Escherichia coli and Staphylococcus aureus [73]. In bovine kefir derived from $\beta$-casein proteolysis, 236 peptides were detected and found to display antimicrobial, antioxidant, angiotensin-converting enzyme (ACE)-inhibitory, immunomodulation and antithrombotic effects [72]. Amorim et al. identified 35 peptides in bovine milk kefir that exhibited an antihypertensive effect mediated via inhibition of ACE activity [74].

\section{Kefir's Biological Properties in the Context of Its Different Manufacturing Practices}

The search for new bioactive chemicals is an ongoing effort. Fermented functional foods, including kefir, are a focus of this research [12]. Kefir possesses a myriad of bioactive properties to include anticancer [11], antimicrobial [73], anti-inflammatory [75], hypocholesterolemic [76], wound healing [77], antioxidant [56] and gastrointestinal aiding properties as summarized in Figure 5 [12], which will be discussed in details over the next subsections.

\subsection{Anticancer Activity}

Cancer is a major health problem worldwide, and requests for functional foods or nutritional supplements that can provide benefit in the treatment of cancer are on the rise [10].

Several studies have suggested the potential antitumor properties of kefir against breast cancer [78], colorectal cancer [79], and malignant T lymphocytes [80]. The cytotoxic effects of standard kefir extract against a panel of seven human cancer cell lines, including breast cancer (MCF-7), chronic myelogenous leukaemia (K562), lung cancer (A549), pancreatic cancer (PANC1), prostate cancer (PC3), ovarian cancer (SKOV3), and colorectal cancer (HCT116) revealed that kefir exhibits anticancer action against human $\mathrm{K} 562$ and HCT11 cells, with $\mathrm{IC}_{50}$ values of 11.36 and $17.39 \mathrm{mg} / \mathrm{mL}$, respectively [81]. The regular consumption of kefir appears to lower colon tumour incidence in mice, suggesting that kefir mitigates against the development of pre-neoplastic lesions chemically induced by azoxymethane at $15 \mathrm{~mL} / \mathrm{kg}$ for 8 weeks of consumption [82]. The use of kefir before and during doxorubicin treatment was found to prevent against doxorubicin's heart-toxic effect in Sprague Dawley rats [83]. Usage of a mixture of 6 LAB from Japanese homemade kefir proved to be efficacious against HCT116, K562, and human natural killer KHYG-1 [84]. Donkey milk-based kefir administered at a dose of $0.5 \mathrm{~mL} /$ day reduced the tumour size of solid Ehrlich ascites carcinoma in a mouse model via its anti-proliferative action by regulating iNOS, eNOS and apoptosis induction [85]. Kefir's cancer cell inhibition mechanism is suggested to be via cell cycle arrest and the induction of apoptosis through upregulating $B A X$ and downregulating BCL2 genes [86]. Chemicals present in kefir powder (commercial kefir in Japan) to mediate for these effects include sphingomyelin that promotes the secretion of anti-proliferative cytokines (particularly IFN- $\beta$ ) in human osteosarcoma cells [87].

The notable positive effects of kefir on cancer cell lines encourage its consumption as a functional diet in cancer prevention, especially in the case of intestinal cancer [88] and colorectal cancer [79]. Nevertheless, it should be noted that such evidence still lacks clinical trials and is mostly based on cell culture-based assays.

\subsection{Hypocholesterolemic Effect}

Hypercholesterolemia is a predisposing factor for cardiovascular disease and can lead to death [89]. Usage of kefir powder at 0.1 and $0.2 \%$ inhibited fat accumulation in adipose and liver tissues of high-fat 
diet (HFD)-induced obese mice. Kefir diminished bodyweight and lowered serum triacylglycerol (TG), total cholesterol (TC), and low-density lipoprotein (LDL) in mice [76]. The administration of kefir $(140 \mathrm{mg} / \mathrm{kg}$ BW/day) for 4 weeks improved fatty liver status via decreasing TG and TC amounts in mice [90]. In HFD-C57BL/6 mice fed with orally administrated kefir (once a day for 12 weeks), a significant decrease of body weight ( $34.18 \mathrm{~g}$ vs. $40.24 \mathrm{~g}$ ) compared to control (milk group) was observed. Kefir's hypocholesterolemia effect is mediated via the up-regulation of genes involved in fatty acid oxidation [91]. Administration of the non-bacterial fraction of kefir ( $22 \mathrm{~mL} / \mathrm{kg}$ for 4 weeks) as a treatment for HFD led to a reduction of lipid deposition in arteries [92], suggesting that chemicals, not microorganisms, mediate for such an effect. Kefir peptides significantly increase fatty acid oxidation via the induction of phosphorylated AMP-activated protein kinase, peroxisome proliferator-activated receptor- $\alpha$, and hepatic carnitine palmitoyltransferase- 1 in mice livers. In addition, kefir peptides significantly reduced the inflammatory response (TNF- $\alpha$, IL-1 $\beta$ and TGF- $\beta$ ) in the liver associated with oxidative damage [93]. The insoluble peptide fraction $(\mathrm{Fr}-3)(0.1 \mathrm{mg} / \mathrm{mL})$ present in kefir significantly decreased lipid accumulation and glycerol-3-phosphate dehydrogenase (GPDH) activity without affecting cell viability, concurrent with a reduction in mRNA expression of adipocyte-specific genes (aP2, FAS and ACC) [94]. Lactobacillus isolates from kefir grains and the administration of Lactobacillus plantarum Lp09 and Lp45 for 4 weeks in rats fed an enriched cholesterol diet showed significantly decreased cholesterol, TC and LDL cholesterol levels in serum as well as cholesterol and TC levels in the liver compared to the control group. Bile acid and fecal cholesterol were significantly increased after LAB consumption [95]. Hypercholesterolemic rats feeding with Lactobacillus plantarum (Lp27) from Tibetan kefir grains at a dose of $10^{9} \mathrm{CFU} / \mathrm{d}$ for 4 weeks led to reduced LDL and TC levels, without affecting HDL. The mechanism of this reduction in cholesterol absorption due to kefir consumption was mediated via the down-regulation of Niemann-Pick C1-Like 1 (NPC1L1 is a critical protein for intestinal cholesterol absorption) expression in Caco-2 cells [96]. Three Lactobacillus strains, including L. plantarum B23, L. acidophilus LA15 and L. kefiri D17, isolated from Tibetan kefir grains showed a reduction of TC, TG and LDL cholesterol levels in the LAB-treated rats. Additionally, both fecal cholesterol and bile acid levels were significantly increased post LAB administration [97].

The soluble non-bacterial fraction of kefir decreased lipid deposition independent of hypercholesterolemia in LDLr-/-mice [92], likely attributed to kefir peptides content found effective to improve body weight, energy intake, and protection against fatty liver [98]. Peptides derived from the microbial fermentation of milk protein account for many fermented dairy products' reported health benefits and are likely to be same in the case of kefir. Compared to other effects, it appears that kefir's hypocholesterolemic effect is the most elucidated at the mechanistic level, positioning it to be formulated in special functional foods used for obesity treatment.

\subsection{Antimicrobial Activities}

Kefir exerts an antibacterial effect against several microorganisms, including S. aureus, E. coli, and Salmonella enteritidis, higher than that achieved using standard antibiotics such as ampicillin [99]. This effect is attributed to its carbohydrate content. Consequently, kefir grain, kefir suspension, and kefiran, a water-soluble polysaccharide of the kefir grain, were tested for antimicrobial activity against several bacterial and fungal pathogens. The highest activity was revealed against Streptococcus faecalis KR6 and Fusarium graminearum CZ1. Aflatoxin is a hazardous chemical produced in stored grains that causes liver cancer, warranting its monitoring to ensure safety levels. Kefir inhibited Aspergillus spore formation and aflatoxin B1 production at $7-10 \%(v / v)$ [100]. Bovine tuberculosis is the result of infection with Mycobacterium bovis transmitted to humans through the consumption of infected raw and raw fermented dairy products. Kefir lowered the viability of $M$. bovis in milk mediated via increasing fermentation time with a directly proportional effect on $M$. bovis inhibition. A $24 \mathrm{~h}$ or shorter fermentation did not ensure the inactivation of M. bovis BCG [101]. A suspension of Lactobacillus diolivorans $1 Z$ (isolated from Brazilian kefir grains) inhibited the growth of Salmonella enterica serovar Typhimurium with a higher survival rate (70\%) than in control mice [102]. 
The antimicrobial peptide Bacteriocin F1, isolated from Tibetan kefir and made up of 18 amino acids, exhibited a bacteriostatic action at $62.5 \mu \mathrm{g} / \mathrm{mL}$ against Escherichia. coli. The antimicrobial activity is mediated via outer and inner membrane leakage of the E. coli cell. Bacteriocin F1 offers an added advantage of being stable against heat, $\mathrm{pH}$ and protease treatment, positing its usage in food preservation [73,103]. Lactobacillus plantarum C4 isolated from kefir exerts a protective effect against intestinal infection caused by Yersinia enterocolitica. Such protection is further associated with a pro-inflammatory status in the intestinal mucosa and concurrent with an increase in the production of secreted immunoglobulin A (IgA) [104]. Streptococcus mutans and S. sobrinus are the main bacterial causes of dental caries. Lactobacillus strains (Lactobacillus kefiranofaciens DD2) isolated from kefir led to growth inhibition and anti-biofilm formation against both microbes [105]. Lactobacillus kefiranofaciens M1 mitigated against enterohemorrhagic E. coli (EHEC) infection, bacterial translocation, intestinal damage, and renal damage, whereas L. plantarum isolated from kefir mixture inhibited the Shigella invasion of Hep-2 cell culture [106]. Except for a few animal-based studies, most antimicrobial action for kefir was studied using direct growth inhibition assays and has yet to be generalized using in vivo based assays in live tissues post oral administration.

\subsection{Wound Healing}

A wound is a physical injury caused by the opening or breaking of the skin. Wounds are problematic for a large number of patients, with more than six million patients suffering from chronic wounds worldwide/year [107]. A topical application of a 70\% kefir gel was used to cure cutaneous wounds in a Wistar rat model. Kefir enhanced wound healing compared to neomycin-clostebol after the seventh day of the experiment [108]. The efficacy was explained by the presence of bioactive ingredients, that is, the acetic acid and lactic acid produced by the bacteria. The correlation between the concentration of active substances and the efficacy of probiotic therapy was thought to be debatable, and more studies are thus warranted. In a rat model, wounds treated with L. acidophilus showed higher healing progress post-burn compared to Eucerin ointment. The L. acidophilus is believed to act via its anti-inflammatory action, accelerating the granulation tissue formation and re-epithelialization [109]. In diabetic foot ulcer (DFU) patients, kefir supplementation for 12 weeks led to a significant reduction in ulcer size [110]. Kefir improved proliferation and migration of human dermal fibroblast (HDF) cells, reduced IL- $1 \beta$ and transforming growth factor- $\beta 1$ (TGF- $\beta 1$ ) expression in parallel with stimulation of basic fibroblast growth factor (bFGF). Kefir's bacteriostatic effect against Pseudomonas aeruginosa and S. aureus growth contributed to the faster healing of burn wounds [111]. The wound healing activity and antimicrobial effects of kefir gel were tested in rat burn wounds infected with Pseudomonas aeruginosa, using an antimicrobial kefir gel that was found to have an effect similar to the positive control, silver sulfadiazine ointment. However, the kefir gel showed a slower wound healing time [112].

\subsection{Anti-Inflammatory and Antioxidant Activities}

Ten weeks of kefir supplementation in spontaneously hypertensive rats was able to reduce inflammatory cytokine (IL-1 $\beta$ ) expression in adipose tissue, increase anti-inflammatory cytokine (IL-10) and decrease the oxidative markers malondialdehyde (MDA) and hydroperoxides [75].

Extracellular vesicles (EV) produced from kefir can ease the TNF-induced inflammation in intestinal cells by inhibiting inflammatory cytokine production. Treatment of each kefir-derived Lactobacillus EV onto TNF- $\alpha$-stimulated Caco-2 cells significantly reduced mRNA expression and secretion of IL-8. Western blot analysis revealed that such an effect was related to TNF- $\alpha$ signalling inhibition mediated by reducing p65 phosphorylation, a subunit of NF-kB. Subsequent application of kefir-derived Lactobacillus EV into inflammatory bowel disease-induced mice significantly alleviated associated symptoms such as body weight loss and rectal bleeding and enhanced stool consistency [113]. Kefir led to a $42 \%$ reduction of TNF- $\alpha / \mathrm{IL}-10$ and a 50\% reduction of pro-inflammatory IL-6 level ratio, concurrent with an enhancement of anti-inflammatory IL-10 level [92]. The lyophilized Tibetan kefir polysaccharide extract 
exhibited good inhibitory action of hyaluronidase enzyme with minimal activity at $2.08 \mathrm{mg} / \mathrm{mL}$ [75]. Kefiran exhibits nitric oxide scavenging activity at $10 \mathrm{mg} / \mathrm{mL}$ comparable to that of quercetin [114].

The antioxidant capacity of kefir made from ewe milk was superior to that prepared from cow milk, posing ewes as a better source of milk to produce kefir used as an antioxidant. The biological effects of kefir from different milk types have yet to be thoroughly identified with respect to major effects. Kefir samples fermented using grain exhibited a stronger antioxidant capacity for 2,2-diphenyl1-picrylhydrazyl (DPPH) and 2,2'-azino-di(3-ethylbenzthiazolin-sulfonate) (ABTS) than kefir samples fermented by starter culture storage. This experiment suggested that ewe milk kefir exhibited an antioxidant effect in the ABTS assay [115].

During milk fermentation, EPS isolated from Tibetan kefir grains exhibited an in vitro antioxidant activity and concentration-dependent protection of protein from oxidative damage [56]. The addition of kefir to apple juice was found to enhance its total phenolic content (TPC) and antioxidant activities [116]. Peanut milk kefir extract displayed stronger antioxidant properties than peanut milk alone, suggesting a fermentation impact of kefir grain on peanut milk's efficacy [66]. Kefir containing a mixture of soy and cow milk exhibited higher antioxidant activity compared to cow kefir (positive control), with antioxidant action attributed to the presence of phenolic compounds that increased after fermentation [5].

Ebner et al. determined 257 peptide sequences from bovine milk kefir, of which the three peptide sequences VYPFPGPIPN, ARHPHPHLSFM and YQEPVLGPVRGPFPIIV exhibited an antioxidant effect [72]. Kefiran was found to possess a beneficial antioxidant effect against reactive oxygen species [117].

\subsection{Anti-Diabetic Activity}

Kefir has demonstrated promising effects in alleviating obesity and associated metabolic dysfunction [118]. Administration of kefir prepared using goat milk and black rice extract showed a similar effect to that of glibenclamide as an anti-diabetic agent [117]. Additionally, feeding of diabetic rats with kefir made from goat milk and soy milk demonstrated an anti-diabetic action as evidenced by a decrease in plasma glucose level concurrent with an increase in glutathione peroxidase (GPx) activity and improved insulin release [119]. An investigation of the active chemicals mediating the antidiabetic effect of kefir has yet to be conducted.

\subsection{Gastrointestinal Tract Effects and Gut Microbiota Modulation}

Kefir administered orally, once daily for four weeks at 4.3 and $10.7 \mathrm{~g} / \mathrm{kg}$ BW/day, modulated gut microbiota composition and yielded anti-fatigue activity by lowering plasma lactate, ammonia and creatine kinase levels, thereby increasing physical performance, forelimb grip strength and the swimming time to exhaustion in mice [12]. Whether kefir can be provided as a supplement for athletes has yet to be fully examined. Additional evidence for kefir's gut microbiota modulation effect was demonstrated from kefiran's capacity to change faecal and gut microbiota of BALB/c mice via increasing the number of Bifidobacteria populations, without a change in Lactobacillus populations [120]. Pre-treatment with a microbial mixture containing bacteria and yeasts isolated from kefir inhibited Shigella flexneri from internalising into human intestinal epithelial cells and led to the attenuation of the inflammatory response [121]. Feeding mice with kefir reduces protozoan Giardia intestinalis infection and promotes the activation of different mechanisms of humoral and cellular immunity that are down-regulated by this parasitic infection [122]. Kefir supernatant and dried kefir powder both exerted radiation-protective effects on the small intestinal mucosa [123], suggesting that these kefir products can aid in alleviating radiation therapy treatment against cancer. Oral administration of kefir averted diarrhoea and enterocolitis triggered by Clostridium difficile [124].

In summary, many studies have demonstrated the biological activities of kefir highlighting its potential as an antioxidant, antimicrobial, anti-inflammatory, wound healing and hypocholesterolemic agent (Figure 5). Nevertheless, further studies of long-term effects on animal and human models are still needed to prove kefir's efficacy. 


\section{Milk vs. Sugar Kefir Limitations and Safety}

While kefir is well recognized for its potential health value as an excellent source of probiotics, some limitations in kefir consumption need to be recognized. These limitations are mostly due to its cholesterol-rich content [125] and potential to trigger allergic reactions. Adapting to non-dairy substrates could be an alternative way to obtain the beneficial health effects from kefir, as exemplified in sugary kefir. A brown sugar solution is the main alternative substrate used nowadays in the fermentation of kefir and produces a beverage known as sugar kefir. Sugary kefir possesses a similar microbial association as traditional milk kefir fermentation, especially lactic acid bacteria and yeast species such as Lactobacillus, Leuconostoc, Kluyveromyces pichia and Saccharomyces. Sugary kefir was found to be more effective at improving the lipid profile in mice than milk kefir [125]. As far as structure, associated microorganisms and products formed during the fermentation process are concerned, sugar kefir grains are quite similar to the milk kefir grains. Melon, carrot, onion, tomato, fennel and strawberry juices have been used as fermentable substrates to produce kefir on which LAB and yeasts could grow [16]. Among these substrates, microorganisms showed the best growth on melon juice. Esters were the major volatile compounds in onion, melon, and strawberry juices, and terpenoids were abundant in fennel and carrot. Aside from improving kefir's aroma, onion, tomato and strawberry juices were found to contribute to its strong antioxidant effect [126]. For a review of sugary kefir's microbiological, biochemical, and functional aspects, the work of Fiorda et al. (2017) ought to be consulted [16].

Questions of quality control and the safety of kefir material have always been relevant to the dairy industry. However, little attention has been given to the safe use of kefir. The literature contains sparse information on the safe levels of kefir intake or the amount to be consumed and the time needed to exert beneficial health effects.

Hemolysis is a common virulence factor among pathogens, with bacterial hemolytic activity being the first safety parameter evaluated in vitro. Another important safety feature is antibiotic sensitivity [127].

Lactobacilli are microorganisms that are useful in dairy technology (cheese, yoghurt and fermented milk) and have a long documented history of food use. L. kefiri strains did not cause $\alpha$-or $\beta$-hemolysis and were found susceptible to tetracycline, clindamycin, streptomycin, ampicillin, erythromycin, kanamycin and gentamicin. L. kefiri strains could inhibit pathogens from both gram-positive and negative bacteria. The mice model receiving an oral dose of L. kefiri CIDCA 8348 daily $\left(10^{8} \mathrm{CFU}\right)$ did not show signs of pain, lethargy, dehydration or diarrhoea, or differences in food and water intake over 21 days. During necropsy, no signs of inflammation or damage were observed in any organ; no differences in the secretion of proinflammatory cytokines between treated and control mice were observed [52]. L. mali K8 showed pH 2.5 tolerance and resisted the damaging effects of bile salts, pepsin, and pancreatin, similar to L. rhamnosus (reference strain). L. mali $\mathrm{K} 8$ was found susceptible to all tested antibiotics except vancomycin. The safety of the L. mali $\mathrm{K} 8$ strain was indicated by a lack of hemolytic activity and its susceptibility to the five standard antibiotics chloramphenicol, oxacillin, tetracycline, penicillin $G$ and ciprofloxacin [128]. The three L. paracasei strains (MRS55, MRS59, and M1743) showing the undesirable activity of trypsin, $\alpha$-chymotrypsin, and $\beta$-glucuronidase were not detected [127] in 32 different LAB strains isolated from Brazilian kefir grains.

Aflatoxin G1 (AFG1) is one of the main toxic contaminants in nuts and causes potential health hazards. Hence, AFG1 reduction is one of the main concerns of food safety. Using kefir grain has a significant effect on AFG1 decontamination in pistachio nuts. The optimized biological detoxification method using $70{ }^{\circ} \mathrm{C}$ treated kefir grains could be suitable for routine removal of AFG1 [129] from pistachios. In Wistar rats, kefir supplementation with a normal dose $(0.7 \mathrm{~mL} /$ day/animal $)$ and high dose ( $3.5 \mathrm{~mL} /$ day/animal) for 4 weeks did not show harmful effects on animals as determined by rat growth, haematology, and blood chemistry, as well as potential pathogenicity in tissues. These findings clearly show that both the normal and high dose of kefir is safe for consumption. The results highlight that although no damage was observed in the mucosa due to the high consumption dose of kefir, the normal dose is recommended due to the most pronounced beneficial effects [130]. 
Enterococcus durans strains could inhibit various pathogens of gram-positive and negative bacteria. These strains were able to survive simulated gastrointestinal conditions and showed similar adhesion power to mucins. Notably, E.durans strains exhibited anti-inflammatory properties as shown by significant flagellin-induced response inhibition of Caco-2 cells. The results showed that $E$. durans does not pose a threat to the health of consumers and demonstrate its potential both as a functional food and as a source of probiotics [131].

\section{Concluding Remarks and Future Directions in Kefir}

Kefir is a popular ethnic dairy product that is constantly subjected to development; different additives of flavours, milk types, fibres, grains, and many more have been examined for the market. Kefir is made from various types of milk (cow, goat, camel, buffalo, or mare), and is usually produced by mixing two types of milk to enhance its benefits, flavor, and texture, and subjected to secondary fermentation or the addition of additives such as inulin to improve the final product properties. The fermentation of kefir grains in a raw sugar solution or sugar from fruits or vegetables without using milk is another way of producing kefir. This product is called sugary kefir. These additives and different production methods, aside from affecting palatability, also affect kefir's physicochemical properties and health benefits. The type of milk used, the kefir grain and the fermentation conditions of production (time and temperature) should be monitored during manufacture as any changes in these variables can impact kefir's chemical and microbiological composition.

The compiled literature in this review sheds light on some of the most noteworthy components assessed using chemical and sensory analyses. Studies reported in this review on kefir production primarily determined the influence of a single variable on the product quality or composition; the interactions between the variables have not been fully examined. It would be necessary to simultaneously investigate the influence of different variables on the quality of the final product using statistical design to optimize kefir fermentation conditions. Another recommended approach is to apply advanced data analyses to design models for comparing products, designating the most effective additives and better achievement of optimal kefir properties. Metabolomics, as a strategy for identification of detailed fermented milk composition and record of biochemical changes due to bacterial activity during the fermentation process and storage, can be readily applied to predict the sensory, nutritional, and safety measures of kefir. A myriad of macro- and micronutrients are encompassed within kefir including proteins, lipids, amino acids, and vitamins. These components account for kefir's antibacterial, immunological, chemopreventive, and hypocholesterolemic effects and for why kefir can be consumed by people who have lactose intolerance.

Most of these health effects are based on biochemical or laboratory assays and need to be substantiated by studies in animals and humans to be more conclusive. Additionally, monitoring changes in the human gut microbiome after ingesting the different probiotics available in kefir products can provide a better understanding of its many health benefits.

Author Contributions: M.A.F. designed the review and made the tables and figures, A.A.E.-W. and S.A.J. wrote the review, H.R.E.-S. revised it. All authors have read and agreed to the published version of the manuscript.

Funding: This research received no external funding.

Acknowledgments: M.A.F. thanks Jesour grant number 30 from the Academy of Scientific Research \& Technology (ASRT), Egypt and the Alexander von Humboldt Foundation, Germany for financial support. H.R.El-S. is very grateful to the Swedish Research links grant 2016-05885 (VR for the years 2017-2019) for generous financial support.

Conflicts of Interest: The authors declare no competing interests.

\section{References}

1. Prado, M.R.; Blandón, L.M.; Vandenberghe, L.P.S. Milk kefir: Composition, microbial cultures, biological activities, and related products. Front. Microbiol. 2015, 6, 1177-1186. [CrossRef] [PubMed] 
2. Cais-Sokolińska, D.; Wójtowski, J.; Pikul, J.; Danków, R.; Majcher, M.; Teichert, J.; Bagnicka, E. Formation of volatile compounds in kefir made of goat and sheep milk with high polyunsaturated fatty acid content. J. Dairy Sci. 2015, 98, 6692-6705. [CrossRef] [PubMed]

3. Kavas, G. Kefirs manufactured from camel (camelus dramedarius) milk and cow milk: Comparison of some chemical and microbial properties. Ital. J. Food Sci. 2015, 27, 357-365.

4. Sun, Z.; Zhang, H.; Yu, Z.; Hou, Q.; Zheng, Y.; Zhong, Z.; Menghe, B.; Kwok, L. Bacterial microbiota compositions of naturally fermented milk are shaped by both geographic origin and sample type. J. Dairy Sci. 2016, 99, 7832-7841.

5. Karaçalı, R.; Özdemİr, N.; Çon, A.H. Aromatic and functional aspects of kefir produced using soya milk and Bifidobacterium species. Int. J. Dairy Technol. 2018, 71, 921-933. [CrossRef]

6. Kim, D.; Chon, J.; Kim, H.; Seo, K. Modulation of intestinal microbiota in mice by kefir administration. Food Sci. Biotechnol. 2015, 24, 1397-1403. [CrossRef]

7. Liu, J.; Wang, S.; Chen, M.; Chen, H.; Yueh, P.; Lin, C. Hypocholesterolaemic effects of milk-kefir and soyamilk-kefir in cholesterol-fed hamsters. Br. J. Nutr. 2014, 95, 939-946. [CrossRef]

8. Liu, J.; Wang, S.; Chen, M.; Yueh, P.; Lin, C. The anti-allergenic properties of milk kefir and soymilk kefir and their beneficial effects on the intestinal microflora. J. Sci. Food Agric. 2006, 2533, 2527-2533. [CrossRef]

9. Miao, J.; Guo, H.; Chen, F.; Zhao, L.; He, L.; Ou, Y.; Huang, M.; Zhang, Y.; Guo, B.; Cao, Y.; et al. Antibacterial effects of a cell-penetrating peptide isolated from kefir. AgriculuraL Food Chem. 2016, 64, 3234-3242. [CrossRef]

10. Sharifi, M.; Moridnia, A.; Mortazavi, D.; Salehi, M. Kefir: A powerful probiotics with anticancer properties. Med. Oncol. 2017, 34, 183-189. [CrossRef]

11. Khoury, N.; El-Hayek, S.; Tarras, O.; El-Sabban, M.; El-Sibai, M.; Rizk, S. Kefir exhibits anti-proliferative and pro-apoptotic effects on colon adenocarcinoma cells with no significant effects on cell migration and invasion. Int. J. Oncol. 2014, 45, 2117-2127. [CrossRef] [PubMed]

12. Hsu, Y.; Huang, W.; Lin, J.; Chen, Y.; Huang, C.; Tung, Y. Kefir supplementation modifies gut microbiota composition, reduces physical fatigue, and improves exercise performance in mice. Nurients 2018, 10, 862. [CrossRef] [PubMed]

13. Kıvanç, M.; Yapıcı, E. kefir as a probiotic dairy beverage: Determination lactic acid bacteria and yeast. ETP Int. J. Food Eng. 2016, 1, 55-60. [CrossRef]

14. Cais-sokolińska, D.; Wójtowski, J.; Pikul, J. Rheological, texture and sensory properties of kefir from mare 's milk and its mixtures with goat and sheep milk. Mljekarstvo 2016, 66, 272-281. [CrossRef]

15. Glibowski, P.; Kowalska, A. Rheological, texture and sensory properties of kefir with high performance and native inulin. J. Food Eng. J. 2012, 111, 299-304. [CrossRef]

16. Fiorda, F.A.; de Melo Pereira, G.V.; Thomaz-Soccol, V.; Rakshit, S.K.; Pagnoncelli, M.G.B.; de Souza Vandenberghe, L.P.; Soccol, C.R. Microbiological, biochemical, and functional aspects of sugary kefir fermentation-A review. Food Microbiol. 2017, 66, 86-95. [CrossRef]

17. Kim, D.H.; Jeong, D.; Song, K.Y.; Seo, K.H. Comparison of traditional and backslopping methods for kefir fermentation based on physicochemical and microbiological characteristics. Food Sci. Technol. 2018, 97, 503-507. [CrossRef]

18. Gulitz, A.; Stadie, J.; Wenning, M.; Ehrmann, M.A.; Vogel, R.F. The microbial diversity of water kefir. Int. J. Food Microbiol. 2011, 151, 284-288. [CrossRef]

19. Shrivastava, N.; Ananthanarayan, L. Use of the backslopping method for accelerated and nutritionally enriched idli fermentation. J. Sci. Food Agric. 2015, 95, 2081-2087. [CrossRef]

20. Yıldız-Akgül, F.; Yetişemiyen, A.; Şenel, E.; Yıldırım, Z. Microbiological, physicochemical, and sensory characteristics of kefir produced by secondary. Mljekarstvo 2018, 68, 201-213. [CrossRef]

21. Lopitz-Otsoa, F.; Rementeria, A.; Elguezabala, N.; Garaizar, J. Kefir: A stmbiotic yeasts-bacteria community with alleged healthy capabilities. Rev. Iberoam Micol. 2006, 23, 67-74. [CrossRef]

22. Machado, A.; Leite, D.O.; Antonio, M.; Miguel, L.; Peixoto, R.S.; Rosado, A.S.; Silva, J.T.; Margaret, V.; Paschoalin, F. Microbiological, technological and therapeutic properties of kefir: A natural probiotic beverage. Brazilian J. Microbiol. 2013, 44, 341-349.

23. Teijeiro, M.; Pérez, P.F.; De Antoni, G.L.; Golowczyc, M.A. Suitability of kefir powder production using spray drying. Food Res. Int. 2018, 112, 169-174. [CrossRef] [PubMed]

24. Atalar, I.; Dervisoglu, M. Optimization of spray drying process parameters for ke fi r powder using response surface methodology. LWT Food Sci. Technol. 2015, 60, 751-757. [CrossRef] 
25. Bolla, P.A.; Serradell, M.D.L.A.; De Urraza, P.J.; De Antoni, G.L. Effect of freeze-drying on viability and in vitro probiotic properties of a mixture of lactic acid bacteria and yeasts isolated from kefir. J. Dairy Res. 2011, 78, 13-32. [CrossRef] [PubMed]

26. Broeckx, G.; Vandenheuvel, D.; Claes, I.J.J.; Lebeer, S.; Kiekens, F. Drying techniques of probiotic bacteria as an important step towards the development of novel pharmabiotics. Int. J. Pharm. 2016, 505, 303-318. [CrossRef]

27. Gul, O.; Mortas, M.; Atalar, I.; Dervisoglu, M.; Kahyaoglu, T. Manufacture and characterization of kefir made from cow and buffalo milk, using kefir grain and starter culture. J. Dairy Sci. 2015, 98, 1517-1525. [CrossRef]

28. Setyawardani, T.; Rahardjo, A. Physiochemical and organoleptic features of goat milk kefir made of different kefir grain concentration on controlled fermentation. Anim. Prod. J. 2014, 16, 48-54.

29. Zhou, J.; Liu, X.; Jiang, H.; Dong, M. Analysis of the microflora in Tibetan kefir grains using denaturing gradient gel electrophoresis. Food Microbiol. 2009, 26, 770-775. [CrossRef]

30. Irigoyen, A.; Arana, I.; Castiella, M.; Torre, P.; Ib, F.C. Microbiological, physicochemical, and sensory characteristics of kefir during storage. Food Chem. 2005, 90, 613-620. [CrossRef]

31. Ozcan, T.; Sahin, S.; Akpinar-Bayizit, A.; Yilmaz-Ersan, L. Assessment of antioxidant capacity by method comparison and amino acid characterisation in buffalo milk kefir. Int. J. Dairy Technol. 2019, 72, 65-73. [CrossRef]

32. Ismaiel, A.A.; Ghaly, M.F.; El-Naggar, A.K. Some physicochemical analyses of kefir produced under different fermentation conditions. J. Sci. Ind. Res. (India). 2011, 70, 365-372.

33. Arslan, S. A review: Chemical, microbiological and nutritional characteristics of kefir. CyTA J. Food 2015, 13, 340-345. [CrossRef]

34. Hu, J.B.; Gunathilake, S.; Chen, Y.C.; Urban, P.L. On the dynamics of kefir volatome. RSC Adv. 2014, 4, 28865-28870. [CrossRef]

35. Magalhães, K.T.; de Melo Pereira, G.V.; Campos, C.R.; Dragone, G.; Schwan, R.F. Brazilian kefir: Structure, microbial communities and chemical composition. Brazilian J. Microbiol. 2011, 42, 693-702. [CrossRef]

36. Gao, W.; Zhang, L. Comparative analysis of the microbial community composition between Tibetan kefir grains and milks. Food Res. Int. 2019, 116, 137-144. [CrossRef] [PubMed]

37. Zhou, J.Z.; Liu, X.L.; Huang, K.H.; Dong, M.S.; Jiang, H.H. Application of the mixture design to design the formulation of pure cultures in Tibetan kefir. Agric. Sci. China 2008, 6, 1383-1389. [CrossRef]

38. Aghlara, A.; Mustafa, S.; Manap, Y.A.; Mohamad, R. Characterization of headspace volatile flavor compounds formed during kefir production: Application of solid phase microextraction. Int. J. Food Prop. 2009, 12, 808-818. [CrossRef]

39. Wszolek, M.; Tamime, A.Y.; Muir, D.D.; Barclay, M.N.I. Properties of kefir made in scotland and poland using bovine, caprine and ovine milk with different starter cultures. LWT Food Sci. Technol. 2001, 34, 251-261. [CrossRef]

40. Cais-Sokolińska, D.; Danków, R.; Pikul, J. Physicochemical and sensory characteristics of sheep kefir during storage. Acta Sci. Pol. Technol. Aliment. 2008, 7, 63-73.

41. Wang, X.; Xiao, J.; Jia, Y.; Pan, Y.; Wang, Y. Lactobacillus kefiranofaciens, the sole dominant and stable bacterial species, exhibits colonization in Tibetan kefir distinct morphotypes upon grains. Heliyon 2018, 4, e00649. [CrossRef]

42. Sabir, F.; Beyatli, Y.; Cokmus, C.; Onal-Darilmaz, D. Assessment of potential probiotic properties of Lactobacillus spp., Lactococcus spp., and Pediococcus spp. strains isolated from kefir. J. Food Sci. 2010, 75. [CrossRef]

43. Dertli, E.; Hilmi, A. Microbial diversity of traditional kefir grains and their role on kefir aroma. LWT-Food Sci. Technol. 2017, 85, 151-157. [CrossRef]

44. Ju, S.Y.; Kim, J.H.; Lee, P.C. Long-term adaptive evolution of Leuconostoc mesenteroides for enhancement of lactic acid tolerance and production. Biotechnol. Biofuels 2016, 9, 240-253. [CrossRef]

45. Assadi, M.M.; Pourahmad, R.; Moazami, N. Use of isolated kefir starter cultures in kefir production. World J. Microbiol. Biotechnol. 2000, 16, 541-543. [CrossRef]

46. Yüksekdag, Z.N.; Beyatli, Y.; Aslim, B. Determination of some characteristics coccoid forms of lactic acid bacteria isolated from Turkish kefirs with natural probiotic. LWT-Food Sci. Technol. 2004, 37, 663-667. [CrossRef]

47. Gientka, I.; Kieliszek, M.; Jermacz, K.; Błazejak, S. Identification and characterization of oleaginous yeast isolated from kefir and its ability to accumulate intracellular fats in deproteinated potato wastewater with different carbon sources. Biomed Res. Int. 2017, 2017. [CrossRef] [PubMed] 
48. Leroi, F.; Pidoux, M. Characterization of interactions between Lactobacillus hilgardii and Saccharomyces florentinus isolated from sugary kefir grains. J. Appl. Bacteriol. 1993, 74, 54-60. [CrossRef]

49. Zafar, S.; Owais, M. Ethanol production from crude whey by Kluyveromyces marxianus. Biochem. Eng. J. 2006, 27, 295-298. [CrossRef]

50. Verce, M.; De Vuyst, L.; Weckx, S. Shotgun metagenomics of a water kefir fermentation ecosystem reveals a novel oenococcus species. Front. Microbiol. 2019, 10, 479-494. [CrossRef] [PubMed]

51. Chen, T.; Wang, S.; Chen, K.; Liu, J.; Chen, M. Microbiological and chemical properties of kefir manufactured by entrapped microorganisms isolated from kefir grains. J. Dairy Sci. 2009, 92, 3002-3013. [CrossRef]

52. Carasi, P.; Racedo, S.M.; Jacquot, C.; Romanin, D.E.; Serradell, M.A.; Urdaci, M.C. Impact of kefir derived Lactobacillus kefiri on the mucosal immune response and gut microbiota. J. Immunol. Res. 2015, 2015, 1-12. [CrossRef]

53. Beshkova, D.M.; Simova, E.D.; Simov, Z.I.; Frengova, G.I.; Spasov, Z.N. Pure cultures for making kefir. Food Microbiol. 2002, 19, 537-544. [CrossRef]

54. Walsh, A.M.; Crispie, F.; Kilcawley, K.; O'Sullivan, O.; O'Sullivan, M.G.; Claesson, M.J.; Cotter, P.D. Microbial succession and flavor production in the fermented dairy beverage kefir. Msystems 2016, 1, e00052-16. [CrossRef]

55. Wang, J.; Zhao, X.; Tian, Z.; Yang, Y.; Yang, Z. Characterization of an exopolysaccharide produced by Lactobacillus plantarum YW11 isolated from Tibet Kefir. Carbohydr. Polym. 2015, 125, 16-25. [CrossRef]

56. Chen, Z.; Shi, J.; Yang, X.; Nan, B.; Liu, Y.; Wang, Z. Chemical and physical characteristics and antioxidant activities of the exopolysaccharide produced by Tibetan kefir grains during milk fermentation. Int. Dairy J. 2015, 43, 15-21. [CrossRef]

57. Jeong, D.; Kim, D.H.; Kang, I.B.; Kim, H.; Song, K.Y.; Kim, H.S.; Seo, K.H. Characterization and antibacterial activity of a novel exopolysaccharide produced by Lactobacillus kefiranofaciens DN1 isolated from kefir. Food Control 2017, 78, 436-442. [CrossRef]

58. Öner, Z.; Karahan, A.G.; Çakmakçı, M.L. Effects of different milk types and starter cultures on kefir. Gida 2009, 7, 1-6.

59. Paraskevopoulou, A.; Athanasiadis, I.; Blekas, G.; Koutinas, A.A.; Kanellaki, M. Influence of polysaccharide addition on stability of a cheese whey kefir-milk mixture. Food Hydrocoll. 2003, 17, 615-620. [CrossRef]

60. Vasiliki, L.; Georgia, D.; Aikatarini, K. Effects of greek pomegranate extracts in the antioxidant properties and storage stability of kefir. Curr. Bioact. Compd. 2019, 15, 437-441.

61. Gul, O.; Dervisoglu, M. Rheological, textural, colour and sensorial properties of kefir produced with buffalo milk using kefir grains and starter culture: A comparison with cows ' milk kefir. Int. J. Dairy Technol. 2018, 71, 73-80. [CrossRef]

62. Said, N.S.; Fahrodi, D.U.; Malaka, R.; Maruddin, F. The physicochemical, microbiology, and sensory characteristics of kefir goat milk with different levels of kefir grain. Trop. Anim. Sci. J. 2019, 42, 152-158.

63. Bakhshandeh, T.; Pourahmad, R.; Sharifan, A.; Moghimi, A. Evaluation of flavor and aroma compounds present in kefir. J. Food Biosci. Technol. 2011, 1, 11-18.

64. Dimitreli, G.; Petridis, D.; Kapageridis, N.; Mixiou, M. Effect of pomegranate juice and fir honey addition on the rheological and sensory properties of kefir-type products differing in their fat content. LWT-Food Sci. Technol. 2019, 111, 799-808. [CrossRef]

65. Farag, M.A.; Wessjohann, L.A. Metabolome classification of commercial Hypericum perforatum (St. John's Wort) preparations via UPLC-qTOF-MS and chemometrics. Planta Med. 2012, 78, 488-496. [CrossRef]

66. Bensmira, M.; Jiang, B. Total phenolic compounds and antioxidant activity of a novel peanut based kefir. Food Sci. Biotechnol 2015, 24, 1055-1060. [CrossRef]

67. Sarkar, S. Potential of kefir as a dietetic beverage-A review. Br. Food J. 2007, 109, 280-290. [CrossRef]

68. Simova, E.; Simov, Z.; Beshkova, D.; Frengova, G.; Dimitrov, Z.; Spasov, Z. Amino acid profiles of lactic acid bacteria, isolated from kefir grains and kefir starter made from them. Int. J. Food Microbiol. 2006, 107, 112-123. [CrossRef]

69. Grohmann, U.; Bronte, V. Control of immune response by amino acid metabolism. Immunol. Rev. 2010, 236, 243-264. [CrossRef]

70. Bifari, F.; Nisoli, E. Branched-chain amino acids differently modulate catabolic and anabolic states in mammals: A pharmacological point of view. Br. J. Pharmacol. 2017, 174, 1366-1377. [CrossRef] 
71. Bakircioglu, D.; Topraksever, N.; Yurtsever, S.; Kizildere, M.; Kurtulus, Y.B. Investigation of macro, micro and toxic element concentrations of milk and fermented milks products by using an inductively coupled plasma optical emission spectrometer, to improve food safety in Turkey. Microchem. J. 2018, 136, 133-138. [CrossRef]

72. Ebner, J.; Aşçi Arslan, A.; Fedorova, M.; Hoffmann, R.; Küçükçetin, A.; Pischetsrieder, M. Peptide profiling of bovine kefir reveals 236 unique peptides released from caseins during its production by starter culture or kefir grains. J. Proteomics 2015, 117, 41-57. [CrossRef] [PubMed]

73. Miao, J.; Liu, G.; Ke, C.; Fan, W.; Li, C.; Chen, Y.; Dixon, W.; Song, M.; Cao, Y.; Xiao, H. Inhibitory effects of a novel antimicrobial peptide from kefir against Escherichia coli. Food Control 2016, 65, 63-72. [CrossRef]

74. Amorim, F.G.; Coitinho, L.B.; Dias, A.T.; Gomes, A.; Friques, F.; Monteiro, B.L.; Dias, L.C.; Rezende, D.; De Melo, T.; Pereira, C.; et al. Identification of new bioactive peptides from kefir milk through proteopeptidomics: Bioprospection of antihypertensive molecules. Food Chem. 2019, 282, 109-119. [CrossRef]

75. Rosa, D.D.; Grześkowiak, Ł.M.; Ferreira, C.L.; Fonseca, A.C.M.; Reis, S.A.; Dias, M.M.; Siqueira, N.P.; Silva, L.L.; Neves, C.A.; Oliveira, L.L.; et al. Kefir reduces insulin resistance and inflammatory cytokine expression in an animal model of metabolic syndrome. Food Funct. 2016, 7, 3390-3401. [CrossRef]

76. Cho, H.-Y.; Choi, J.-W.; Kang, H.W.; Kim, M.-K.; Lim, W.-C.; Lee, I.-Y. Kefir prevented excess fat accumulation in diet-induced obese mice. Biosci. Biotechnol. Biochem. 2017, 81, 958-965. [CrossRef]

77. Tsiouris, C.G.; Kelesi, M.; Vasilopoulos, G.; Kalemikerakis, I.; Papageorgiou, E.G. The efficacy of probiotics as pharmacological treatment of cutaneous wounds: Meta-analysis of animal studies. Eur. J. Pharm. Sci. 2017, 104, 230-239. [CrossRef]

78. Chen, C.; Chan, H.M.; Kubow, S. Kefir extracts suppress in vitro proliferation of estrogen-dependent human breast cancer cells but not normal mammary epithelial cells. J. Med. Food 2007, 10, 416-422. [CrossRef]

79. Dos Reis, S.A.; da Conceição, L.L.; Dias, M.M.; Siqueira, N.P.; Rosa, D.D.; de Oliveira, L.L.; da Matta, S.L.P.; Peluzio, M.D.C.G. Kefir reduces the incidence of pre-neoplastic lesions in an animal model for colorectal cancer. J. Funct. Foods 2019, 53, 1-6. [CrossRef]

80. Rizk, S.; Maalouf, K.; Baydoun, E. The antiproliferative effect of kefir cell-free fraction on hut-102 malignant $\mathrm{t}$ lymphocytes. Clin. Lymphoma Myeloma 2009, 9, S198-S203. [CrossRef]

81. Hatmal, M.M.; Nuirat, A.; Zihlif, M.A.; Taha, M.O. Exploring the influence of culture conditions on kefir's anticancer properties. J. Dairy Sci. 2018, 101, 3771-3777. [CrossRef] [PubMed]

82. De Paula Melo, A.F.; Mendonça, M.C.P.; de Mendonça Rosa-Castro, R. The protective effects of fermented kefir milk on azoxymethane-induced aberrant crypt formation in mice colon. Tissue Cell 2018, 52, 51-56. [CrossRef]

83. Boeneke, C.; O’Brien, K.; Lisano, J.K.; Hayward, R.; Smoak, P.; Mathias, A.; Stewart, L.K.; Christensen, M.; Hydock, D.S. Milk and kefir maintain aspects of health during doxorubicin treatment in rats. J. Dairy Sci. 2019, 102, 1910-1917.

84. Yamane, T.; Sakamoto, T.; Nakagaki, T.; Nakano, Y. Lactic acid bacteria from kefir increase cytotoxicity of natural killer cells to tumor cells. Foods 2018, 7, 48. [CrossRef]

85. Esener, O.B.B.; Balkan, B.M.; Armutak, E.I.; Uvez, A.; Yildiz, G.; Hafizoglu, M.; Yilmazer, N.; Gurel-Gurevin, E. Donkey milk kefir induces apoptosis and suppresses proliferation of Ehrlich ascites carcinoma by decreasing iNOS in mice. Biotech. Histochem. 2018, 93, 424-431. [CrossRef]

86. Gao, J.; Gu, F.; Ruan, H.; Chen, Q.; He, J.; He, G. Induction of apoptosis of gastric cancer cells SGC7901 in vitro by a cell-free fraction of Tibetan kefir. Int. Dairy J. 2013, 30, 14-18. [CrossRef]

87. Osada, K.; Nagira, K.; Teruya, K.; Tachibana, H.; Shirahata, S.; Murakami, H. Enhancement of interferon- $\beta$ production with sphingomyelin from fermented milk. Biotherapy 1993, 7, 115-123. [CrossRef] [PubMed]

88. Güzel-Seydim, Z.B.; Ece Cagdas, M.D.; Seydim, A.C. Effect of kefir on fusobacterium nucleatum potentially causing intestinal cancer. Funct. Foods Heal. Dis. 2016, 6, 469-477. [CrossRef]

89. Wong, B.; Kruse, G.; Kutikova, L.; Ray, K.K.; Mata, P.; Bruckert, E. Cardiovascular disease risk associated with familial hypercholesterolemia: A systematic review of the literature. Clin. Ther. 2016, 38, 1696-1709. [CrossRef]

90. Chen, H.L.; Tung, Y.T.; Tsai, C.L.; Lai, C.W.; Lai, Z.L.; Tsai, H.C.; Lin, Y.L.; Wang, C.H.; Chen, C.M. Kefir improves fatty liver syndrome by inhibiting the lipogenesis pathway in leptin-deficient ob/ob knockout mice. Int. J. Obes. 2014, 38, 1172-1179. [CrossRef]

91. Kim, D.H.; Kim, H.; Jeong, D.; Kang, I.B.; Chon, J.W.; Kim, H.S.; Song, K.Y.; Seo, K.H. Kefir alleviates obesity and hepatic steatosis in high-fat diet-fed mice by modulation of gut microbiota and mycobiota: Targeted and 
untargeted community analysis with correlation of biomarkers. J. Nutr. Biochem. 2017, 44, 35-43. [CrossRef] [PubMed]

92. Andrade, T.U.; Porto, M.L.; Filete, P.F.; Abdalla, D.S.P.; Lima, E.M.; Pereira, T.M.C.; Meyrelles, S.S.; Lenz, D.; Vasquez, E.C.; Santanna, A.F.; et al. Chronic administration of the soluble, nonbacterial fraction of kefir attenuates lipid deposition in LDLr -/- mice. Nutrition 2016, 35, 100-105.

93. Tung, Y.T.; Chen, H.L.; Wu, H.S.; Ho, M.H.; Chong, K.Y.; Chen, C.M. Kefir peptides prevent hyperlipidemia and obesity in high-fat-diet-induced obese rats via lipid metabolism modulation. Mol. Nutr. Food Res. 2018, 62, 1700505-1700513. [CrossRef] [PubMed]

94. Ho, J.; Choi, J.; Lim, W.; Kim, M. Kefir inhibits 3T3-L1 adipocyte differentiation through down-regulation of adipogenic. J. Sci. Food Agric. 2013, 93, 485-490. [CrossRef]

95. Huang, Y.; Wang, X.; Wang, J.; Wu, F.; Sui, Y.; Yang, L.; Wang, Z. Lactobacillus plantarum strains as potential probiotic cultures with cholesterol-lowering activity. J. Dairy Sci. 2013, 96, 2746-2753. [CrossRef]

96. Huang, Y.; Wu, F.; Wang, X.; Sui, Y.; Yang, L.; Wang, J. Characterization of Lactobacillus plantarum Lp27 isolated from Tibetan kefir grains: A potential probiotic bacterium with cholesterol-lowering effects. J. Dairy Sci. 2013, 96, 2816-2825. [CrossRef]

97. Zheng, Y.; Lu, Y.; Wang, J.; Yang, L.; Pan, C.; Huang, Y. Probiotic properties of lactobacillus strains isolated from tibetan kefir grains. PLoS One 2013, 8, e69868-e69877. [CrossRef]

98. Chen, H.L.; Tsai, T.C.; Tsai, Y.C.; Liao, J.W.; Yen, C.C.; Chen, C.M. Kefir peptides prevent high-fructose corn syrup-induced non-alcoholic fatty liver disease in a murine model by modulation of inflammation and the JAK2 signaling pathway. Nutr. Diabetes 2016, 6, e237-e245. [CrossRef]

99. Abdel-mogheith, S.; El-gendy, A.O. Exploring the antimicrobial and hepatoprotective effects of kefir; a probiotic fermented milk. J. Pure Appl. Microbiol. 2017, 11, 759-772. [CrossRef]

100. Ismaiel, A.A.; Ghaly, M.F.; El-Naggar, A.K. Milk kefir: Ultrastructure, antimicrobial activity and efficacy on aflatoxin b1 production by Aspergillus flavus. Curr. Microbiol. 2011, 62, 1602-1609. [CrossRef]

101. Macuamule, C.L.S.; Wiid, I.J.; van Helden, P.D.; Tanner, M.; Witthuhn, R.C. Effect of milk fermentation by kefir grains and selected single strains of lactic acid bacteria on the survival of Mycobacterium bovis BCG. Int. J. Food Microbiol. 2016, 217, 170-176. [CrossRef] [PubMed]

102. Nicoli, J.R.; Neumann, E.; Arantes, R.M.E.; Abatemarco Júnior, M.; Nunes, Á.C.; Sandes, S.H.C.; Ricci, M.F. Protective effect of Lactobacillus diolivorans 1Z, isolated from Brazilian kefir, against Salmonella enterica serovar Typhimurium in experimental murine models. Front. Microbiol. 2018, 9, 2856-2867.

103. Miao, J.; Guo, H.; Ou, Y.; Liu, G.; Fang, X.; Liao, Z.; Ke, C.; Chen, Y.; Zhao, L.; Cao, Y. Purification and characterization of bacteriocin F1, a novel bacteriocin produced by Lactobacillus paracasei subsp. tolerans FX-6 from Tibetan kefir, a traditional fermented milk from Tibet, China. Food Control 2014, 42, 48-53. [CrossRef]

104. De Montijo-Prieto, S.; Moreno, E.; Bergillos-Meca, T.; Lasserrot, A.; Ruiz-López, M.D.; Ruiz-Bravo, A.; Jiménez-Valera, M. A Lactobacillus plantarum strain isolated from kefir protects against intestinal infection with Yersinia enterocolitica O9 and modulates immunity in mice. Res. Microbiol. 2015, 166, 626-632. [CrossRef] [PubMed]

105. Jeong, D.; Kim, D.H.; Song, K.Y.; Seo, K.H. Antimicrobial and anti-biofilm activities of Lactobacillus kefiranofaciens DD2 against oral pathogens. J. Oral Microbiol. 2018, 10, 1472985-1472993. [CrossRef]

106. Kakisu, E.; Bolla, P.; Abraham, A.G.; de Urraza, P.; De Antoni, G.L. Lactobacillus plantarum isolated from kefir: Protection of cultured Hep-2 cells against Shigella invasion. Int. Dairy J. 2013, 33, 22-26. [CrossRef]

107. Wang, R.; Lechtenberg, M.; Sendker, J.; Petereit, F.; Deters, A.; Hensel, A. Wound-healing plants from TCM: In vitro investigations on selected TCM plants and their in fl uence on human dermal fi broblasts and keratinocytes. Fitoterapia 2013, 84, 308-317. [CrossRef]

108. Rodrigues, K.L.; Gaudino Caputo, L.R.; Tavares Carvalho, J.C.; Evangelista, J.; Schneedorf, J.M. Antimicrobial and healing activity of kefir and kefiran extract. Int. J. Antimicrob. Agents 2005, 25, 404-408. [CrossRef]

109. Barzegari, A.A.; Hashemzaei, M.; Majdani, R.; Alihemmati, A.-R. Effects of topical treatment of second-degree burn wounds with Lactobacillus acidophilus on the wound healing process in male rats. Pharm. Biomed. Res. 2018, 3, 23-30. [CrossRef]

110. Mohseni, S.; Bayani, M.; Bahmani, F.; Tajabadi-Ebrahimi, M.; Bayani, M.A.; Jafari, P.; Asemi, Z. The beneficial effects of probiotic administration on wound healing and metabolic status in patients with diabetic foot ulcer: A randomized, double-blind, placebo-controlled trial. Diabetes. Metab. Res. Rev. 2018, 34, 1-8. [CrossRef] 
111. Oryan, A.; Alemzadeh, E.; Eskandari, M.H. Kefir accelerates burn wound healing through inducing fibroblast cell migration in vitro and modulating the expression of IL-1 $\beta$, TGF- $\beta 1$, and bFGF genes in vivo. Probiotics Antimicrob. Proteins 2018, 11, 788-790.

112. Huseini, H.F.; Rahimzadeh, G.; Fazeli, M.R.; Mehrazma, M.; Salehi, M. Evaluation of wound healing activities of kefir products. Burns 2012, 38, 719-723. [CrossRef] [PubMed]

113. Seo, M.K.; Park, E.J.; Ko, S.Y.; Choi, E.W.; Kim, S. Therapeutic effects of kefir grain Lactobacillus -derived extracellular vesicles in mice with 2, 4, 6-trinitrobenzene sulfonic acid-induced inflammatory bowel disease. J. Dairy Sci. 2018, 101, 8662-8671. [CrossRef] [PubMed]

114. Radhouani, H.; Gonçalves, C.; Maia, F.R.; Oliveira, J.M.; Reis, R.L. Biological performance of a promising Kefiran-biopolymer with potential in regenerative medicine applications: A comparative study with hyaluronic acid. J. Mater. Sci. Mater. Med. 2018, 29, 124-133. [CrossRef]

115. Yilmaz-Ersan, L.; Ozcan, T.; Akpinar-Bayizit, A.; Sahin, S. Comparison of antioxidant capacity of cow and ewe milk kefirs. J. Dairy Sci. 2018, 101, 3788-3798. [CrossRef]

116. Sabokbar, N.; Khodaiyan, F.; Moosavi-Nasab, M. Optimization of processing conditions to improve antioxidant activities of apple juice and whey based novel beverage fermented by kefir grains. J. Food Sci. Technol. 2015, 52, 3422-3432. [CrossRef]

117. Nurliyani; Sadewa, A.H.; Sunarti. Kefir properties prepared with goat milk and black rice (Oryza sativa L.) extract and its influence on the improvement of pancreatic $\beta$-cells in diabetic rats. Emirates J. Food Agric. 2015, 27, 727-735. [CrossRef]

118. Bourrie, B.C.T.; Cotter, P.D.; Willing, B.P. Traditional kefir reduces weight gain and improves plasma and liver lipid profiles more successfully than a commercial equivalent in a mouse model of obesity. J. Funct. Foods 2018, 46, 29-37. [CrossRef]

119. Harmayani, E. Antidiabetic potential of kefir combination from goat milk and soy milk in rats induced with streptozotocin-nicotinamide. Korean J. Food Sci. Anim. Resour. 2016, 35, 847-858.

120. Hamet, M.F.; Medrano, M.; Pérez, P.F.; Abraham, A.G. Oral administration of kefiran exerts a bifidogenic effect on BALB/c mice intestinal microbiota. Benef. Microbes 2016, 7, 237-246. [CrossRef]

121. Bolla, P.A.; Abraham, A.G.; Pérez, P.F.; De Los Angeles Serradell, M. Kefir-isolated bacteria and yeasts inhibit Shigella flexneri invasion and modulate pro-inflammatory response on intestinal epithelial cells. Benef. Microbes 2016, 7, 103-110. [CrossRef] [PubMed]

122. Franco, M.C.; Golowczyc, M.A.; De Antoni, G.L.; Pe, P.F. Administration of kefir-fermented milk protects mice against Giardia intestinalis infection Printed in Great Britain. J. Med. Microbiol. 2013, 62, 1815-1822. [CrossRef] [PubMed]

123. Teruya, K.; Myojin-maekawa, Y.; Shimamoto, F.; Watanabe, H.; Nakamichi, N.; Tokumaru, K.; Tokumaru, S.; Shirahata, S. Protective effects of the fermented milk kefir on x-ray irradiation- induced intestinal damage in b6c3f1 mice. Biol. Pharm. Bull. 2013, 36, 352-359. [CrossRef] [PubMed]

124. Bolla, P.A.; Carasi, P.; Angeles, M.; De Antoni, G.L. Anaerobe protective effect of a mixture of kefir isolated lactic acid bacteria and yeasts in a hamster model of clostridium dif fi cile infection. Anaerobe 2013, 21, 28-33. [CrossRef]

125. Corona, O.; Randazzo, W.; Miceli, A.; Guarcello, R.; Francesca, N.; Erten, H.; Moschetti, G.; Settanni, L. Characterization of kefir-like beverages produced from vegetable juices. LWT-Food Sci. Technol. 2016, 66, 572-581. [CrossRef]

126. Bernardeau, M.; Vernoux, J.P.; Henri-Dubernet, S.; Guéguen, M. Safety assessment of dairy microorganisms: The Lactobacillus genus. Int. J. Food Microbiol. 2008, 126, 278-285. [CrossRef]

127. Leite, A.M.O.; Miguel, M.A.L.; Peixoto, R.S.; Paschoalin, V.M.F.; Mayo, B. Probiotic potential of selected lactic acid bacteria strains isolated from Brazilian kefir grains. J. Dairy Sci. 2015, 98, 3622-3632. [CrossRef]

128. Yin, W.; Uthumporn, K.; Rosma, U.; Irfan, A. Evaluation of probiotic potential and anti-hyperglycemic properties of a novel Lactobacillus strain isolated from water kefir grains. Food Sci. Biotechnol. 2018, 27, 1369-1376.

129. Ansari, F.; Khodaiyan, F.; Rezaei, K.; Rahmani, A. Modelling of aflatoxin G1 reduction by kefir grain using response surface methodology. J. Environ. Heal. Sci. Eng. 2015, 13, 1-7. [CrossRef]

130. Rosa, D.D.; Peluzio, M.d.C.G.; Bueno, T.P.; Cañizares, E.V.; Miranda, L.S.; Dorbignyi, B.M.; Dubí, D.C.; Castaño, I.E.; Grzeskowiak, Ł.M.; Ferreira, C.L.L.F. Evaluation of the subchronic toxicity of kefir by oral administration in Wistar rats. Nutr. Hosp. 2014, 29, 1352-1359. 
131. Carasi, P.; Jacquot, C.; Romanin, D.E.; Elie, A.M.; De Antoni, G.L.; Urdaci, M.C.; de los Angeles Serradell, M. Safety and potential beneficial properties of Enterococcus strains isolated from kefir. Int. Dairy J. 2014, 39, 193-200. article distributed under the terms and conditions of the Creative Commons Attribution (CC BY) license (http://creativecommons.org/licenses/by/4.0/). 